\title{
Social Status and Its Relationship to Non-specific Stress at Late Iron Age Non Ban Jak, Northeast Thailand
}

\author{
Stacey M. Ward, ${ }^{\text {a* }}$ Siân E. Halcrow, ${ }^{a}$ Hallie R. Buckley, ${ }^{a}$ Andrew R. Gray, \\ Charles F. W. Higham, ${ }^{c}$ Kate Domett, ${ }^{d}$ Dougald J. W. O'Reilly, ${ }^{e}$ and \\ Louise G. Shewan ${ }^{f}$ \\ ${ }^{a}$ Department of Anatomy, School of Biomedical Sciences, University of Otago, Dunedin, New Zealand \\ ${ }^{b}$ Centre for Biostatistics, Division of Health Sciences, University of Otago, Dunedin, New Zealand \\ 'Department of Anthropology and Archaeology, University of Otago, Dunedin, New Zealand \\ ${ }^{\mathrm{d} C}$ College of Medicine and Dentistry, James Cook University, Townsville, Australia \\ 'School of Archaeology and Anthropology, Australian National University, Canberra, Australia

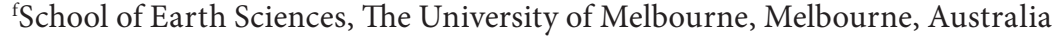 \\ ${ }^{\star}$ Correspondence to: Stacey M. Ward, Department of Anatomy, University of Otago, P.O. Box 56, \\ Dunedin 9054, New Zealand \\ e-mail: stacey.ward@otago.ac.nz
}

ABSTRACT The rise of social inequality is a key development in human history and is linked to deteriorating health. These associated health impacts are poorly understood for Iron Age (420 B.C.-A.D. 500) northeast Thailand. To clarify this issue we investigate whether social status differences influence non-specific stress at the site of Non Ban Jak (A.D. 300-800), which comprises two separate burial mounds. These mounds are thought to represent the neighborhoods of two distinct social groups at the site. Quantitative analyses were used to explore differences in grave goods among the adults of Non Ban Jak $(N=47)$. Long bone lengths, ages at death, and linear enamel hypoplasia (LEH) were examined to explore differences in non-specific stress on the basis of age, sex, burial mound, and mortuary phase. Results demonstrated that older adults of both sexes, males of all ages, and west mound individuals received greater grave good quantities and may therefore have been of higher social status. West mound individuals were taller and had a lower prevalence of LEH compared to those from the east mound. Although female LEH prevalence and mortality were reduced relative to males, decreasing stature over time and high neonatal mortality indicated greater female stress. Lower-status individuals may therefore have suffered increased stress relative to those of higher status. Artifactual and epigraphic evidence supports the suggestion of sex- and class-based status differences at Non Ban Jak, legitimized and perpetuated through the adoption of residential burial and new religious ideologies.

Keywords: grave goods; inequality; health

การปรากฎขึนของความไม่เท่าเทียมทางสังคมเป็นพัฒนาการสำคัญอย่างหนึงในประวัติศาสตร์มนุษยชาติ และเชือมโย งกับสุขภาพที"เสือมลง ความรู้ความเข้าใจเกียวกับสุขภาวะทีเกียวเนืองกับความไม่เท่าเทียมทางสังคมในสมัยเหล็ก (ประมาณ ๒,๔๐० - ๑,๔๐० ปมาแล้ว) ในภาคตะวันออกเฉียงเหนือนียังมีน้อย ดังนัน เพือสร้างความเข้าใจให้ชัดเจนใน เรืองนี เราจึงได้ศึกษาตรวจสอบว่าความแตกต่างด้านสถานะทางสังคมมีอิทธิพลต่อความตึงเครียดหรือไม่ ทังนี เราใช้ หลักฐานทางโบราณคดีจากแหล่งโบราณคดีโนนบ้านจาก (กำหนดอายุระหว่าง ๒,๓о० - ๑,๒०० ปีมาแล้ว) ซึงมีเนิน หลุมฝังศพ ๒ เนิน เราเชือว่าเนินดินหลุมฝังศพทังสองเนินนีเป็นแหล่งฝังศพของกลุ่มคน ๒ กลุ่มทีเป็นเพือนบ้านกัน หรื่อมีความใกล้ชิดทางสังคม เราใช้วิธีการวิ เคราะห์เชิงปริมาณในการศึกษาตรวจสอบความแตกต่างของวัตถุอุทิศที พบ ร่วมกับหลุมฝังศพของคนในวัยที"เป็นผู้ใหญ่ นอกจากนี เรายังวิเคราะห์ความยาวของกระดูกแขน-ขา อายุเมื้อตาย และ 
การเสือมผุของเคลือบฟัน เพือตรวจสอบระดับความแตกต่างของความตึงเครียดตามเพศ อายุ/วัย กลุ่มสังคม และช่วงเวลา ผลการศึกษาพบว่าผู้ใหญ่วัยสูงอายุทังเพศหญิงและชาย ผู้ชายทุกวัย และกลุ่มคนจากเนินฝังศพด้านตะวันตกมีจำนวน วัตถุอุทิ ศมากกว่ากลุ่มคนจากเนินฝังศพทางตะวันออก และดังนันคนทีถูกฝังในเนินดินฝังสพทางตะวันตกอาจจะมี สถานภาพสูงกว่าคนที่ถูกฝงในเนินดินหลุมฝังศพทางตะวันออก คนทีถูกฝังในเนินดินหลุมฝังศพทางตะวันตกมีร่างกาย ทีสูงกว่าและมีการเสื"อมผุของเคลือบฟันน้อยกว่าคนทีฝังที เนินดินทางตะวันออก และแม้ว่าการเสื"อมผุของเคลือบฟัน และอัตราการเสียชีวิตของผู้หญิงลดลงเมือเปรียบเทียบกับผู้ชาย แต่ผู้หญิงก็มีส่วนสูงเฉลียลดลง และมีอัตราการเสีย ชีวิตของทารกในครรภ์สูงขี้นตามช่วงเวลาซึงอาจจะแสดงว่าผู้หญิงมี้ชีวิตความตึงเครียด และคนทีมีสถานภาพทาง สังคมต่าก็มีความตึงเครียดมากกว่าคนทีมีสภาพทางสังคมที้สูงด้วย หลักฐานประเภทโบราณวัตถุและจารึกโบราณ สนับสนนว่าความแตกต่างทางสถานภาพทางสังคมและเพศทีแหล่งโบราณคดี โนนบ้านจากเกิดขึนและดำรงอยู่ดังจะ สะท้อนให้เห็นจากการฝังศพในทีอยู่อาศัยและการเข้ามาของระบบความเชือทางศาสนาอันใหม่

The development of social inequality, defined as resource and power imbalances between groups and individuals of varying social status, is one of the most significant transitions in human history, and it is well established in both modern and ancient societies that it has resounding implications for human health ${ }^{1}$ (Ames 2008; Earle 1987; Feinman 1995; Renfrew and Bahn 2004). Although these health impacts affect all members of unequal societies, they are magnified among individuals of lower status due to inadequate nutrition and greater exposure to unsanitary living conditions and disease vectors (Marmot 2006). This results in an increased proportion of pre-term births, increased infant, maternal, and adult mortality, and a higher prevalence of infectious disease among this portion of society (Adler et al. 1994; Di Cesare et al. 2013; Kawachi and Kennedy 1999; Marmot 2005; Morello-Frosch and Shenassa 2006; Siegrist and Marmot 2006). The indirect costs of illness, such as reduced incomes and depleted financial reserves, further exacerbate inequality through creating a cycle of poverty, institutionalizing the social position of low-status individuals over time (Leatherman and Jernigan 2014).

Consideration of the impacts of inequality is therefore of critical importance when striving to obtain a nuanced view of health in populations where social inequality is present. As a crucial component of stratified state societies, inequality is often considered in archaeological studies focusing on the pathways to state development (Trigger 2003). Inequality is recognized through evidence for the presence of institutionalized status differences between groups of differing identity. As such, investigation of social status provides a first step for understanding inequality.

Bioarchaeological studies, typically employing a biocultural perspective to study past populations, focus on how status shapes an individual's experience of the environment and how this influences health (Mays

1. Here we define health as non-specific stress at the population level, acknowledging that many aspects of health (e.g., mental well-being) are not observable in skeletal remains and that health is a continuum. et al. 2009; Pechenkina et al. 2017; Peck 2013; Redfern and DeWitte 2011; Reitsema and Vercellotti 2012; Robb et al. 2001; M. C. Stewart and Vercellotti 2017). Analyses of non-specific stress are commonly used in these studies as proxies for relative health (Reitsema and Mcllvaine 2014; Temple and Goodman 2014), while identification of status in past populations poses a more difficult question.

Social differentiation, defined here as the differentiation of individuals based on certain identity traits (e.g., age, sex), and variation in status, defined as differences in power and prestige among differentiated individuals, are present in all societies (Price and Feinman 1995; Wason 1994). However, status is temporally, geographically, and culturally variable, and interactions between status and other facets of the identity makes its identification from the archaeological record challenging (Price and Feinman 2010; Wason 1994).

Where available, written documents may allow identification of social status differences within a community. In prehistoric societies, mortuary treatment, and particularly grave offerings, have been used to represent differences in social status (Binford 1971; Wason 1994). However, it is now well established that these items may reflect myriad other factors, such as social beliefs about life and personhood (Ross 2007), acknowledgment of status achieved throughout the lifetime (Ames 2008), and the agenda of the survivors (Fowler 2013; Parker Pearson 1982; Shanks and Tilley 1982). Despite these theoretical difficulties, there has been a recent increase in bioarchaeological research investigating status differences and health in archaeological populations from Europe, the United Kingdom, the Americas, and China (e.g., Pechenkina and Delgado 2006; Pechenkina et al. 2017; Robb et al. 2001; M. C. Stewart and Vercellotti 2017). However, these issues remain relatively unexplored in Southeast Asia.

Recent archaeological research has characterized the Iron Age (420 B.C.-A.D. 500) of northeast Thailand as a period of environmental and economic changes relating to the development of unequal 
societies (Castillo et al. 2018; Higham 2011, 2012, 2014, 2016; Higham and Kijngam 2012; Higham and Rispoli 2014; O'Reilly and Shewan 2015, 2016; O'Reilly et al. in press). Weakening monsoon cycles (Chawchai et al. 2015a, 2015b; Wohlfarth et al. 2016) triggered a shift to intensified wet rice cultivation during this period, evidenced by reservoir construction, new agricultural tools, and wet-field weed species at Iron Age Ban Non Wat, Noen U-Loke, and Non Ban Jak (Fig. 1) (Castillo et al. 2018; O’Reilly 2014; G. Scott and O’Reilly 2015).
The development of unequal societies following these economic and environmental shifts is suggested by the mortuary differentiation of individuals at the Iron Age site of Noen U-Loke (Higham 2014, 2016). Increasing trade of agricultural goods and private land ownership are posited to have provided the mechanisms through which enterprising individuals created and monopolized wealth, which was then represented through grave offerings in death (Hayden 2001; Higham 2012; O’Reilly 2014).

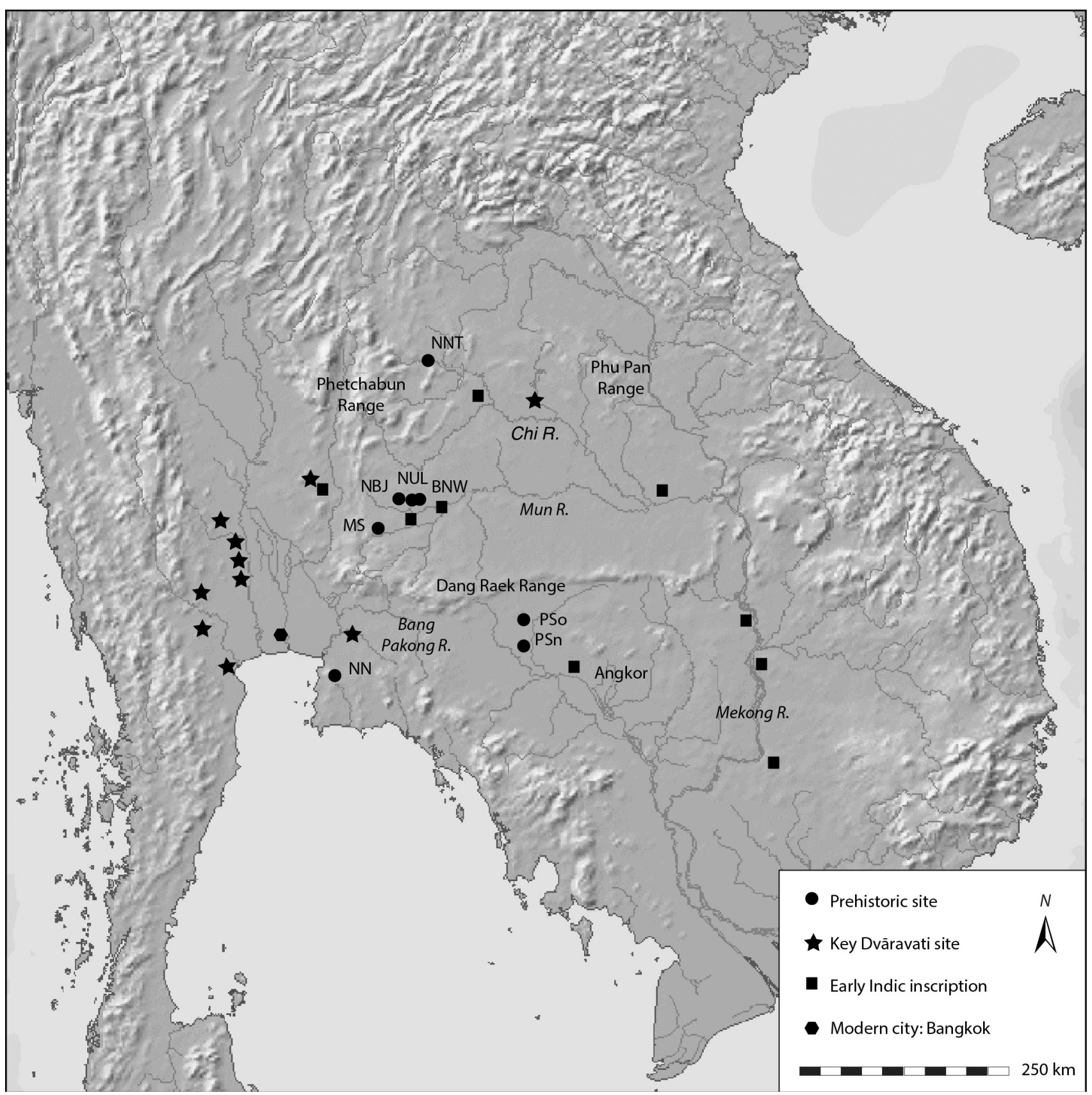

Figure 1. Map of mainland Southeast Asia situating the archaeological sites mentioned in the text. NBJ = Non Ban Jak; NUL = Noen U-Loke; BNW = Ban Non Wat; MS = Muang Sema; NNT = Non Nok Tha; NN = Nong Nor; PSo = Phum Sophy; PSn = Phum Snay. The locations of the early Indic inscriptions are drawn from Vickery (1998) and the Dvāravati sites from Murphy (2016). 
In contrast to archaeological research in the area, the poor preservation of Iron Age skeletal samples in northeast Thailand has largely precluded bioarchaeological study, resulting in a limited understanding of health during this period. The limited evidence gleaned from the Iron Age phase of Ban Non Wat and the site of Noen U-Loke indicates fluctuations in oral health (Shkrum 2014), increased infant and maternal mortality and morbidity (Halcrow et al. 2008, 2016), and an increased prevalence of specific infectious diseases, suggesting a deterioration in health during the late Iron Age (Halcrow et al. 2016; Tayles and Buckley 2004; Tayles et al. 2007). An increasing reliance on wet rice agriculture, reduced dietary diversity, and landscape modification have been implicated as the chief drivers of this health deterioration (Halcrow et al. 2016; King et al. 2014, 2017).

While the development of inequality and a deterioration of health have been hypothesized for the Iron Age of northeast Thailand, investigations of the relationship between health and social status have, as noted, been limited by poor bone preservation in this region. However, the recently excavated late Iron Age site of Non Ban Jak (A.D. 300-800) has, for the first time, provided well-preserved skeletal remains $(n=161)$ from intact mortuary contexts, allowing investigation of the relationship between social status and health. This assemblage constitutes the largest Iron Age skeletal collection in the region to date.

Non Ban Jak is notable for the presence of two distinct but contemporaneous mounds enclosed in a moat system (Higham et al. 2014) (Fig. 2). Observations during excavation revealed that west mound individuals were interred with greater numbers of iron sickles, while the houses of the east mound were thicker-walled (Higham et al. 2014). These differences in energy, labor, and resource investment have led Higham et al. (2014) to hypothesize that each mound's inhabitants represented a distinct social group within Non Ban Jak society, with the east mound representing a purported higher-status group. The separate mounds are believed to represent the "neighborhood" of each group.

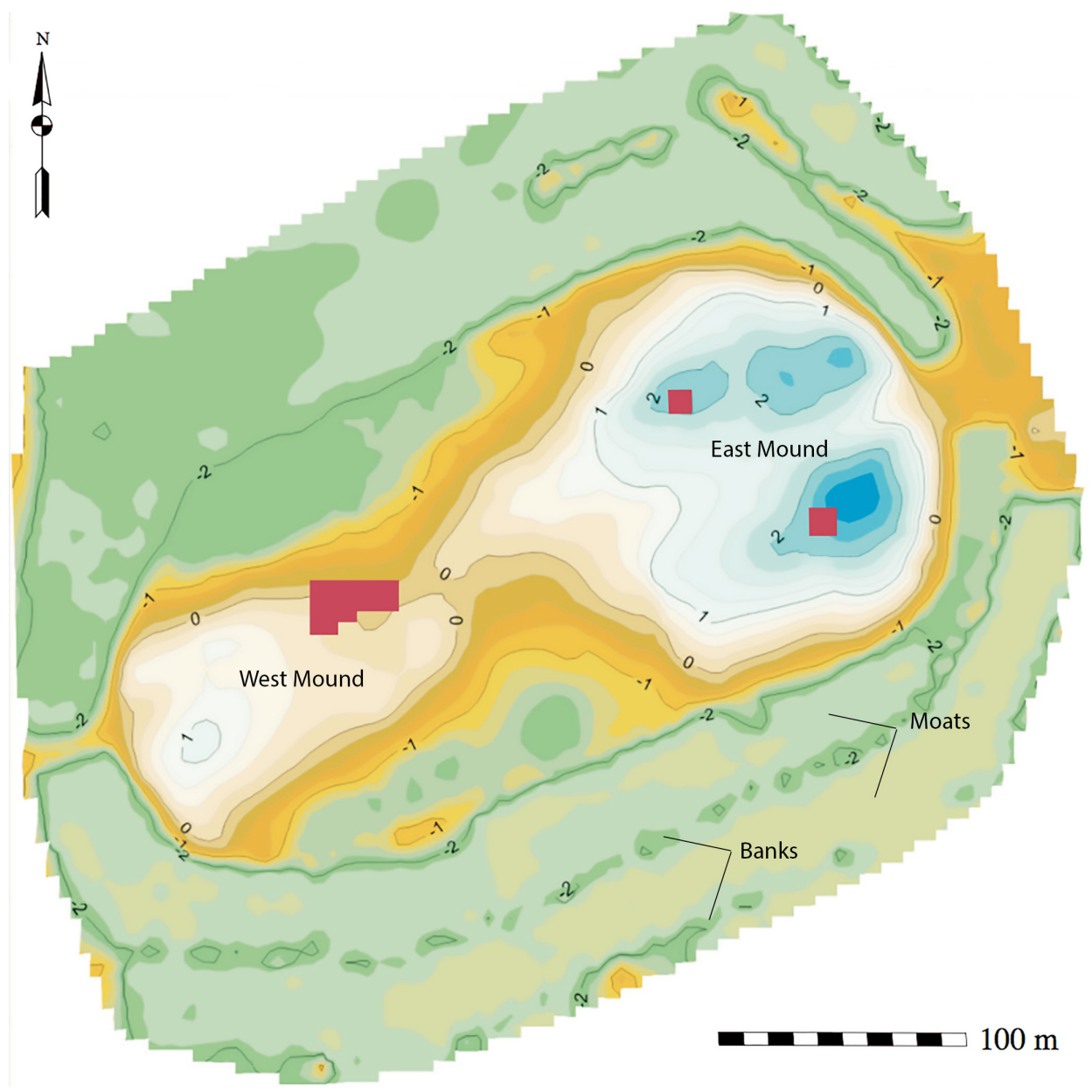

Figure 2. Map of Non Ban Jak showing the east and west mounds and the archaeological excavation areas (squares) opened between 2011 and 2017. The areas between the $-1 \mathrm{~m}$ and $2 \mathrm{~m}$ contour lines represent the built-up mound areas, while areas between the $-1 \mathrm{~m}$ and $-2 \mathrm{~m}$ contour lines are low-lying. Image provided by permission of C. F. W. Higham and N. Chang. 
The discovery of residential burial at Non Ban Jak also has significant implications for the development of social hierarchy (Higham et al. 2019). Houses are corporate landholding entities that receive social rights, duties and obligations and perpetuate themselves through the transmission of their names and wealth through kinship lines (González-Ruibal 2006). Houses can be seen as crucial for the development of inequality, as they represent the materialization of wealth and power and provide a means for its legitimization and display (Gillespie 2000; Waterson 1995). Houses may also be ranked relative to each other and may fission to produce junior and senior lineages (Gillespie 2001). As a symbolic concept, residential burial legitimizes claims to the land and reinforces entitlement to the wealth and privilege of the deceased (Gillespie 2001).

In this article we aim to investigate whether differences in grave goods quantities, representing differences in social status, were present between varying age, sex, and mound groups at the unique site of Non Ban Jak. We also seek to investigate how these possible social differences related to differing experiences of non-specific stress. Based on the archaeological and bioarchaeological information on northeast Thailand to date, we make the following predictions:

Grave good quantities will vary with age, sex and burial mound. Recently it has been argued that quantitative differences in grave goods reflect status differences in Southeast Asia (Ward 2019; also see below). Analysis of how grave good quantities vary by age, sex, and mound may therefore provide insight into the presence of status differences between these groups. This in turn may provide insight into social inequality. To determine which forms of inequality, if any, were operating at Non Ban Jak, we broadly explore grave good differences between all of these demographic categories.

Non-specific stress, represented by LEH and long bone length, will vary with sex and burial mound. Sex differences in labor, diet, and health have been identified through bioarchaeological studies of skeletal remains from various prehistoric sites in northeast Thailand, although these differences vary across sites and over time (Domett 2001; Domett et al. 2011; Douglas 1996; Foster 2011; IkeharaQuebral et al. 2017). These studies show no clear sex differences in LEH prevalence, while male stature appears to increase in later prehistory. We therefore hypothesize that males will show less evidence of non-specific stress at Non Ban Jak. As lower status is associated with poorer health, we hypothesize that the purported high-status east mound individuals will show less evidence of non-specific stress.
Individuals with fewer grave goods will show more evidence of non-specific stress. As noted above, higher quantities of grave goods are interpreted as evidence of higher social status, while lower quantities reflect lower social status. Lower social status has been linked to poor health in both modern and bioarchaeological communities. Therefore, it is expected that at Non Ban Jak, individuals of lower status will show more evidence of non-specific stress. Evidence of greater non-specific stress will manifest as a higher prevalence of LEH, shorter mean long bone lengths, and reduced variation in long bone lengths.

\section{Grave Goods and Social Status}

Mortuary offerings are a common inclusion in burial contexts in a wide range of archaeological settings. Based on ethnographic observations, proponents of the processual perspective argued that increased grave good quality, quantity, and diversity were an accurate indicator of high status (Binford 1971; Brown 1995; O'Shea 1984; Peebles 1971). Differences in social status were seen as representative of social inequality, while the presence or absence of inequality provided insight into social organization (Binford 1971; Saxe 1971; Tainter 1978).

More recently, this approach has been critiqued as not considering human agency, ideology, or symbolism, leading to the placement of greater emphasis on the multifaceted nature of grave goods (Brown 1995; Ekengren 2013; Parker Pearson 1982, 1999; Shanks and Tilley 1982). Although grave goods are viewed as related to social status, it is acknowledged that they may not directly represent social organization due to the fluidity and multiplicity of their meanings (Chapman 2013; Ekengren 2013; Hodder 1982; Ucko 1969). For example, the form, material, frequency, and placement of items may act to obscure the meaning and function of other items (Parker Pearson 1999). Furthermore, identities represented through grave goods may be manipulated by the survivors of the deceased, demonstrating individual agency (Fowler 2013; Parker Pearson 1982; Shanks and Tilley 1982).

To address the complex nature of grave goods, new approaches have been developed that combine bioarchaeological and mortuary information to investigate social difference. "Lived" experiences represented in human skeletal remains may be contrasted with "performed" experiences represented by mortuary offerings to give insight into the overall coherence or dissonance of a society's structuring ideologies (Quinn and Beck 2016). Individual identity, community diversity, and embodied daily experiences also provide alternate routes for the bioarchaeological 
analysis of social difference (Cekalovic 2014; Ross 2019; Schrader 2019; Torres-Rouff et al. 2015), while analyses of trauma and entheseal changes can be used to provide insight into power differentials and roles within society (Schrader 2015; Torres-Rouff et al. 2015).

In Southeast Asia, processually influenced material culture analyses have remained a mainstay in archaeological research. Based on a recent synthesis of 35 years of grave goods studies in Southeast Asia, Ward (2019) has argued that two levels of social signaling were used in prehistoric northeast Thailand. Age, sex, and kin group identity were likely signaled using certain symbolic items (e.g., a particular ceramic form), although these symbols varied regionally and were likely only of local significance (Bayard 1984; Cekalovic 2014; Chang 2001; Heath 2017; O’Reilly 1999; Ross 2007, 2019; see Crass 2001; Peebles 1971; Petré 1993; Shennan 1975 for discussions of sex symbolism in Europe and North America). In contrast, variation in overall grave goods quantities crosscuts this recognition of age and sex, suggesting that these quantitative differences may reflect recognition of an additional facet of the identity such as occupation, ethnicity, or kin group. Despite a lack of critical interrogation of the significance of grave good quantities in Southeast Asia, it is often assumed that they are representative of social status (Higham 2011, 2014, 2016; Talbot 2002 , 2007). The current work assumes that a greater number of grave inclusions represents higher social status and that status differences may indicate the presence of social inequality. However, it is acknowledged that social phenomena such as identity, differentiation, status, and inequality are complex and interacting and that this simplistic view may not accurately reflect the use and meaning of grave goods in prehistoric Thailand.

\section{Non-specific Stress and Its Links to Social Status}

Non-specific stress occurs when external influences alter the equilibrium of the body, triggering an endocrine response (Selye 1950, 1973). This response results in biological trade-offs between survival and normal physiological function (Goodman and Armelagos 1988; Goodman et al. 1980; Sapolsky et al. 1986; Selye 1950).

Physiological trade-offs are important in the bioarchaeological analysis of human remains, as they can result in the development of non-specific stress indicators in the skeleton. These indicators provide insight into stress during periods of environmental and social change, allowing bioarchaeologists to investigate health during major human transitions. Long bone lengths are commonly used as a proxy for stature and can represent stress-related growth disruptions in childhood (Eveleth and Tanner 1991; Jantz et al. 1994). Comparison of long bone lengths within and between populations may reveal disparities in growth that reflect variation in frailty and stress burdens. LEH represents periods of insufficient enamel secretion resulting from stress-related disruptions during tooth development (Goodman and Rose 1990, 1991; Hillson 2005, 2014).

Human clinical studies have shown that these physiological trade-offs are intensified under conditions of social inequality. While individuals may occupy the same environment, their experience of it is mediated by their social status. For example, lower-status individuals are exposed to constant "background stress" stemming from increased risk of disease and insufficient nutrition (Adler et al. 1994), leading to increased stress reactivity (G. W. Evans and Kim 2013; Lynch et al. 1998; Steptoe et al. 2003; Steptoe and Marmot 2002). Thus it is expected that low-status individuals will show more evidence of non-specific stress, although it is possible that these individuals will die before manifesting stress markers in their skeletons (Wood et al. 1992). In contrast, immune responses are strengthened in high-status individuals, suggesting that biological buffering of physiological stress can occur as a result of higher social status (Brunner 1997). However, the amount of protection provided by social status differs between and within populations, and inherent biological frailty varies between individuals, between the sexes, and across different stages of the life course (Eveleth 1975; Goodman and Armelagos 1989; Stini 1969; Stinson 1985, 2012; Tobias 1975).

\section{Materials and Methods}

\section{Non Ban Jak and its skeletal assemblage}

Non Ban Jak is located in Amphoe Non Sung of Nakhon Ratchasima province, northeast Thailand (Fig. 1). Human burials date between A.D. 300-800 (Higham 2015), placing Non Ban Jak in the Iron Age and PreAngkorian periods (A.D. 500-800) (Higham 2014). Site occupation is divided into an early phase (ca. A.D. 300-500) and late phase (ca. A.D. 500-800) based on radiocarbon dates, grave good assemblages, burial superimposition, and burial orientation, allowing for the investigation of change over time.

As noted above, the site is unusual for its doublepeaked occupation mound (Fig. 2). Within the neighborhoods represented by each mound, clay floors and wall foundations suggestive of residential structures have been recorded, and some burials from the site have been recovered from within these domestic contexts (Higham et al. 2014). This custom, 
interpreted as residential burial, has not previously been observed elsewhere in northeast Thailand (Higham 2014, 2015; but see White and Eyre 2010 for an alternate view).

The majority of the site's 161 burials contained subadults $(70.8 \%, 114 / 161)$ (Table 1$)$, with the site having the highest infant and child mortality rates in prehistoric Southeast Asia to date (Buckley et al. in press). The adults of Non Ban Jak (defined as individuals aged 20 years or older) with secure age and sex estimates $(N=47)$ form the focus of the current investigation. The adult skeletal assemblage of the west mound $(n=41)$ is larger than that of the east mound $(n=6)$, although each mound is divided into roughly equal portions of early and late phase individuals (east, three early and three late; west, 21 early and 20 late). The skeletal assemblage as a whole is also divided into roughly equal portions of early $(\mathrm{N}=24)$ and late phase individuals $(\mathrm{N}=23)$.

\section{Assessing social status at Non Ban Jak: Grave goods analysis}

Three groupings of grave goods were explored, adapting category-focused methods established in previous studies of social status in Southeast Asia to increase the comparability of research in this region (e.g., Cekalovic 2014; Higham et al. 2019; Talbot 2002): the total number of items per individual, probable artifact function ("functional categories"), and construction material ("material categories"). Functional categories included ornamental items such as jewelry, utilitarian items such as knives, and "other" items. Material categories comprised clay, metal, stone, glass, shell, and "other." Ceramic items were included as their own functional category, as ceramic vessels may have both ornamental and utilitarian value. Items defined as "other" included eggshells, rounded pebbles, and rice. Although the use of grave good categories requires classifications to be made regarding possible artifact use and construction material, we seek to avoid biased "value" judgments on the meaning and worth of each object (Talbot 2002). Following this system, we have not attempted to define "other" objects to avoid making biased judgments regarding their function (Cekalovic 2014).

\section{Assessing mortality and non-specific stress at Non Ban Jak: Age and sex estimation, osteometrics, and LEH}

Adult age-at-death estimation was performed based on visual observations of morphological changes in the pubic symphysis and auricular surface (Brooks and Suchey 1990; Lovejoy et al. 1985), late fusing epiphyses (Buikstra and Ubelaker 1994), morphological changes of the sternal ends of the ribs (İșcan et al. 1984, 1985), and dental wear (Smith 1984). All adults were placed into broad age categories in keeping with previous bioarchaeological research in Southeast Asia (Tayles and Halcrow 2016): young adult (20-30 years old), middle adult (30-40 years old), and old adult (40+ years). Adult sex estimation was based on observations of cranial and pelvic morphology following Bruzek (2002), Buikstra and Ubelaker (1994) and Phenice (1969). Adult individuals of indeterminate age and sex as well as individuals lacking complete long bones or teeth were excluded from analysis, leaving a total of 47 adults available for the grave goods study, 36 for the long bone length study, and 38 for the LEH analysis.

To investigate stress-related growth disruptions, maximum length measurements were taken for the tibia, fibula, humerus, radius, and ulna, and bicondylar length was measured for the femur following Buikstra and Ubelaker (1994). All measurements were taken using an osteometric board. To investigate the level of long bone asymmetry, intraclass correlation coefficients (ICCs) were estimated using a one-way random effects model for absolute agreement for long bone measurements paired by side. For all long bones, individual ICCs were above 0.91, indicating "excellent" agreement (Koo and Li 2016) (Supporting Information, Online Table S1). Measurements from the left side were given preference but when absent, measurements from the right side were substituted due to low asymmetry.

Macroscopic recording of LEH defects has been a mainstay in bioarchaeological studies of health, and a number of methods have been developed for their analysis. This has resulted in a lack of standardized methods for LEH research. Recently, researchers have also argued for the adoption of microscopic analysis of LEH due to its increased objectivity (Cares Henriquez and Oxenham 2017, 2019). However, these techniques are not yet widely applied in Southeast Asia, and to increase the comparability of the current study to those previously performed in the region, a conservative macroscopic technique was employed.

Criteria for the inclusion of individuals were the presence of at least two teeth with visible buccal or labial surfaces and at least $50 \%$ of the crown remaining. The buccal or lingual surfaces of each tooth were macroscopically investigated under natural outdoor light, and LEH were identified as continuous grooves spanning at least $50 \%$ of the tooth's width. A flat-edged wooden probe and $5 x$ magnification hand lens were used to confirm LEH presence, and defects were recorded following the Fédération Dentaire Internationale Developmental Defects of Dental Enamel Index (1982). For calculation of the age at defect formation, the distance from the occlusal edge of each defect to the cementoenamel junction (CEJ) was 


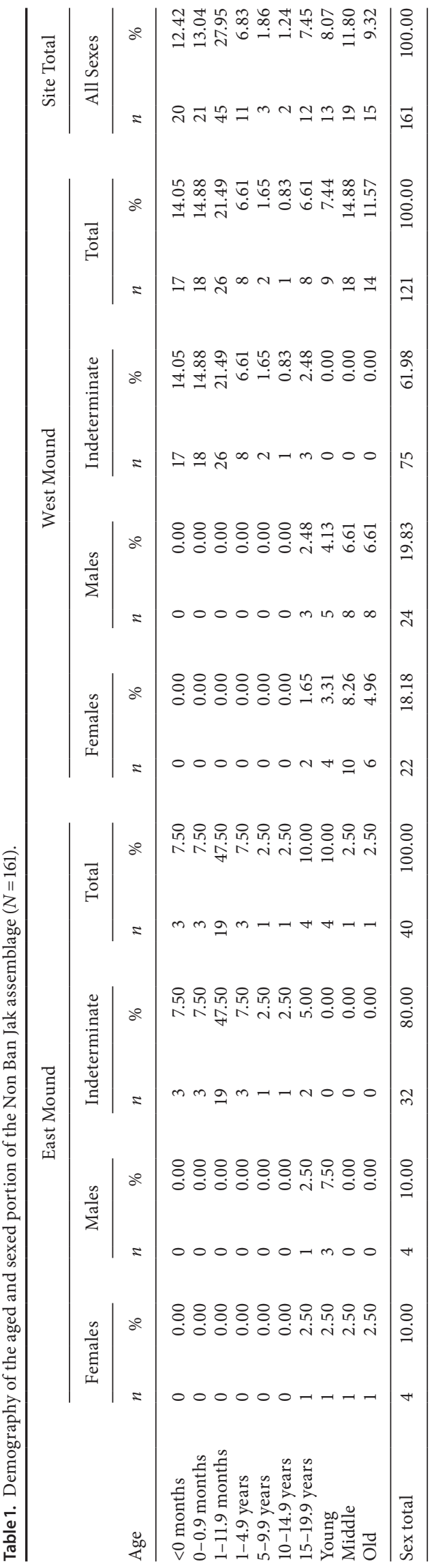


measured using Mitutoyo digital calipers following Buikstra and Ubelaker (1994). Age at formation was then calculated following Goodman and Rose (1991:289). Age at crown completion and years of formation were obtained from Schour and Massler (1940:1920), and average crown heights for each tooth were calculated from unworn teeth from the Non Ban Jak assemblage. Defects were then matched chronologically between the teeth to ensure that only defects representing systemic stress were included (e.g., Clark et al. 2014; Goodman et al. 1980; Littleton 2005). To be considered representative of systemic stress, a defect had to have formed in the same chronological unit as at least one other defect from at least one other tooth. Other forms of enamel hypoplasia (e.g., plane form defects) were excluded from the study due to the difficulty of assigning these defects an age at formation for chronological matching (Hillson and Bond 1997).

\section{Statistical analysis}

All statistical analyses were selected accounting for small sample sizes (Morgan 2017). To investigate variation in grave good quantities where likelihood ratio tests indicated excessive variation within the data distribution, negative binomial regression with incidence rate ratios (IRRs) was used (StataCorp 2019). Where the likelihood test was not significant, Poisson regression was used instead. In both cases, models were developed in a step-forward manner by adding terms, including interactions, depending on sample sizes.

Descriptive statistics were calculated for long bone lengths by sex, mortuary phase, and mound to investigate general trends. Quantile regression was then employed following a backwards selection strategy to investigate the statistical significance of these trends. A Wald test was used to evaluate the simpler model compared to the previous "parent" model. Quantile regression was selected, as it models median values and is therefore less influenced by outlier effects than mean-based regression methods (A. Stewart 2016).

Recent bioarchaeological research has shown that greater stress in a community may result in reduced variation in stature (DeWitte and Hughes-Morey 2012; Hughes-Morey 2016; Vercellotti et al. 2014). To test this hypothesis at Non Ban Jak, Levene's tests for equality of variance were used to assess the statistical significance of differences in long bone length variation between groups.

Chi-squared tests were used to investigate differences in LEH prevalence and demographics between age, sex, phase, and mound groups. Where $20 \%$ or more of the cells of the contingency table had expected cell counts under five, Fisher's exact tests were employed (Kim 2017). All statistical analyses were performed using StataCorp Stata/IC 15.1 for Mac, and the threshold for statistical significance was set at $p<0.05$. The data that support the findings of this study are available from the corresponding author upon reasonable request.

\section{Results}

Variations in grave goods quantities at Non Ban Jak

Grave goods analyses are summarized in Online Tables S2-S7.

Investigation of univariable models showed that total grave goods quantities did not increase significantly with age, and so age was excluded from subsequent modeling $(\mathrm{IRR}=1.10, p=0.286)$. Grave goods quantities were significantly increased among males (IRR $=1.75$, $p=0.045)$, late phase individuals $(\mathrm{IRR}=2.16, p=0.003)$, and individuals from the west mound ( $\mathrm{IRR}=3.39$, $p=0.009$ ). A main effects model was then adopted, which confirmed the increase in grave goods among males (IRR $=1.59, p=0.043)$, late phase $(\mathrm{IRR}=2.22$, $p<0.0001$ ), and west mound individuals (IRR $=3.7$, $p=0.006$ ) when adjusting for the other variables. Interactions models including phase by mound, mound by sex, and phase by sex interactions revealed that only the diachronic change in sex differences in grave goods was significant (Wald test, $p=0.017$ ). This interaction showed that the disparity in grave goods between males and females equalized over time when mound differences in grave goods were removed.

Univariable analysis showed that late phase individuals were interred with significantly greater numbers of ceramics (IRR $=1.82, p=0.024$ ), numbers of metal items $(\mathrm{IRR}=2.65, p=0.007)$, and quantities of utilitarian items $(\operatorname{IRR}=9.56, p<0.001)$ relative to early phase individuals. West mound individuals received significantly greater numbers of ornaments (IRR $=3.42$, $p=0.039$ ). Adjusted models and interactions could not be assessed for the functional and material categories due to small sample sizes, and so confounding interactions of phase and mound cannot be excluded.

\section{Age structure of the mounds}

The west mound comprised a larger assemblage of adult skeletal human remains $(n=41)$ than the east mound $(n=6)$. The east mound had a higher percentage of young adults relative to the west mound, while adults of middle and old aged comprised the largest percentage of the west mound assemblage (Table 1). 
Meanwhile, equal percentages of males and females were present in both mounds. The differences in age group percentages between the mounds were not statistically significant (Fisher's exact test, $p=0.106$ ). Small sample sizes in the east mound precluded statistical analysis of sex differences between the east and west areas of the site.

\section{Non-specific stress at Non Ban Jak}

Descriptive statistics for adult long bone lengths show that male mean long bone lengths increased over time (Table 2). Among the females, long bone lengths decreased over time with the exception of the tibia and fibula. Long bone lengths were largest in the west mound for both males and females (Table 3), while west mound males had greater variation in long bones lengths, represented by the standard deviation and coefficient of variation, than west mound females. In the east mound, females had a greater variety of long bone lengths than males ( $p>0.187$, Online Table S8).

However, an interaction model, which explored whether the sex differences in long bone length changed over time while adjusting for mound differences, was non-significant in all long bones (all interaction $p \geq 0.303$, Table 4). A main effects model exploring the adjusted associations between sex, phase, and mound showed that west mound individuals had longer long bone lengths than east mound individuals. However, this difference was not statistically significant in any bone except the radius $(p=0.034$, all other $p \geq 0.196$, Table 5).

Although a slight increase in the prevalence of LEH with age was observed from young adults to older adults, this increase was not statistically significant (Fisher's exact test, $p=0.276$ ). As such, analyses by sex,

Table 2. Descriptive statistics for long bone lengths by sex and phase.

\begin{tabular}{|c|c|c|c|c|c|c|c|c|c|c|c|}
\hline \multirow[b]{2}{*}{ Long Bone } & \multirow[b]{2}{*}{ Sex } & \multicolumn{5}{|c|}{ Early Phase $(n=22)$} & \multicolumn{5}{|c|}{ Late Phase $(n=14)$} \\
\hline & & $n$ & Mean $(\mathrm{cm})$ & SD & $\mathrm{CV}$ & Median $(\mathrm{cm})$ & $n$ & Mean $(\mathrm{cm})$ & $\mathrm{SD}$ & $\mathrm{CV}$ & $\operatorname{Median}(\mathrm{cm})$ \\
\hline \multirow[t]{2}{*}{ Femur } & Female & 8 & 42.04 & 1.19 & 0.029 & 41.95 & 3 & 41.04 & 2.59 & 0.063 & 40.00 \\
\hline & Male & 7 & 44.44 & 1.71 & 0.039 & 44.50 & 7 & 45.04 & 2.39 & 0.053 & 44.80 \\
\hline \multirow[t]{2}{*}{ Tibia } & Female & 6 & 34.84 & 1.34 & 0.038 & 35.19 & 2 & 36.55 & 1.06 & 0.029 & 36.55 \\
\hline & Male & 6 & 38.25 & 1.92 & 0.050 & 37.85 & 5 & 39.59 & 2.30 & 0.058 & 40.10 \\
\hline \multirow[t]{2}{*}{ Fibula } & Female & 5 & 34.21 & 1.66 & 0.049 & 34.50 & 1 & 36.90 & - & - & 36.90 \\
\hline & Male & 5 & 36.34 & 1.89 & 0.052 & 35.63 & 1 & 39.60 & - & - & 39.60 \\
\hline \multirow[t]{2}{*}{ Humerus } & Female & 8 & 29.65 & 1.14 & 0.039 & 30.02 & 2 & 28.06 & 3.01 & 0.108 & 28.07 \\
\hline & Male & 7 & 31.43 & 1.56 & 0.050 & 32.00 & 6 & 31.58 & 1.13 & 0.036 & 31.49 \\
\hline \multirow[t]{2}{*}{ Radius } & Female & 8 & 23.10 & 1.11 & 0.048 & 23.50 & 3 & 23.03 & 1.58 & 0.069 & 23.90 \\
\hline & Male & 7 & 25.60 & 1.49 & 0.058 & 25.60 & 5 & 25.70 & 1.80 & 0.070 & 25.17 \\
\hline \multirow[t]{2}{*}{ Ulna } & Female & 9 & 24.90 & 1.22 & 0.049 & 25.30 & 3 & 24.86 & 1.70 & 0.069 & 25.70 \\
\hline & Male & 4 & 26.63 & 0.61 & 0.023 & 26.60 & 5 & 28.00 & 1.88 & 0.067 & 27.07 \\
\hline
\end{tabular}

Key: $\mathrm{SD}=$ standard deviation; $\mathrm{CV}=$ coefficient of variation.

Table 3. Descriptive statistics for long bone lengths by sex and mound.

\begin{tabular}{|c|c|c|c|c|c|c|c|c|c|c|c|}
\hline \multirow[b]{2}{*}{ Long Bone } & \multirow[b]{2}{*}{ Sex } & \multicolumn{5}{|c|}{ Early Phase $(n=7)$} & \multicolumn{5}{|c|}{ Late Phase $(n=29)$} \\
\hline & & $n$ & Mean $(\mathrm{cm})$ & $\mathrm{SD}$ & $\mathrm{CV}$ & Median (cm) & $n$ & Mean $(\mathrm{cm})$ & $\mathrm{SD}$ & $\mathrm{CV}$ & Median $(\mathrm{cm})$ \\
\hline \multirow[t]{2}{*}{ Femur } & Female & 2 & 40.95 & 2.57 & 0.063 & 40.95 & 9 & 41.95 & 1.47 & 0.035 & 41.40 \\
\hline & Male & 3 & 43.33 & 1.82 & 0.042 & 43.00 & 11 & 45.13 & 1.98 & 0.044 & 44.80 \\
\hline \multirow[t]{2}{*}{ Tibia } & Female & 0 & - & - & - & - & 8 & 35.27 & 1.43 & 0.041 & 35.59 \\
\hline & Male & 2 & 36.41 & 0.87 & 0.024 & 36.42 & 9 & 39.40 & 1.91 & 0.049 & 40.10 \\
\hline \multirow[t]{2}{*}{ Fibula } & Female & 0 & - & - & - & - & 6 & 34.66 & 1.84 & 0.053 & 34.85 \\
\hline & Male & 3 & 35.17 & 0.40 & 0.011 & 35.00 & 3 & 38.59 & 1.63 & 0.042 & 39.47 \\
\hline \multirow[t]{2}{*}{ Humerus } & Female & 2 & 28.45 & 3.56 & 0.125 & 28.45 & 8 & 29.55 & 1.05 & 0.036 & 30.02 \\
\hline & Male & 3 & 30.95 & 2.11 & 0.068 & 31.10 & 10 & 31.66 & 1.11 & 0.035 & 31.75 \\
\hline \multirow[t]{2}{*}{ Radius } & Female & 2 & 21.38 & 0.26 & 0.012 & 21.39 & 9 & 23.46 & 0.91 & 0.039 & 23.90 \\
\hline & Male & 3 & 24.53 & 0.95 & 0.039 & 24.20 & 9 & 26.01 & 1.57 & 0.060 & 25.30 \\
\hline \multirow[t]{2}{*}{ Ulna } & Female & 3 & 24.10 & 1.25 & 0.052 & 24.00 & 9 & 25.15 & 1.23 & 0.049 & 25.33 \\
\hline & Male & 2 & 26.66 & 0.89 & 0.034 & 26.67 & 7 & 27.60 & 1.70 & 0.062 & 27.00 \\
\hline
\end{tabular}

Key: $\mathrm{SD}=$ standard deviation; $\mathrm{CV}=$ coefficient of variation. 
Table 4. Wald tests assessing the overall significance of the phase by sex interactions model, which investigated change over time between the sexes while removing mound differences.

\begin{tabular}{lcc}
\hline Long Bone & $n$ & p-value \\
\hline Femur & 25 & 0.321 \\
Tibia & 19 & $-^{\dagger}$ \\
Humerus & 23 & 0.758 \\
Radius & 23 & 0.303 \\
Ulna & 21 & 0.833 \\
\hline
\end{tabular}

${ }^{\dagger}$ Small sizes $(<20)$ precluded the exploration of interactions for the tibia.

mound, and phase were conducted using a pooled adult age sample to increase sample sizes. These analyses showed that males, late phase, and east mound individuals had a higher prevalence of LEH relative to females, early phase, and west mound individuals, respectively (Table 6). However, none of these changes were statistically significant.

\section{Discussion}

\section{Social status differences at Non Ban Jak}

The adults of Non Ban Jak received differing quantities and types of grave goods depending on their age, sex, and mound affiliations, although only sex and mound differences were statistically significant. As argued above, grave good types are believed to signal age and sex identity, while variation in grave goods quantities crosscuts typological groups and is believed to represent another aspect of identity, such as kin group, ethnicity, or occupation. In Southeast Asian archaeology, grave goods quantities are believed to represent social status differences, following the processual perspective outlined above. To explore this issue, the findings presented above are contextualized against artifactual and epigraphic analyses spanning the prehistoric, protohistoric, and historic periods of Southeast Asia.

At Non Ban Jak, young individuals of both sexes received fewer grave items relative to older individuals, although this difference was not statistically significant. Age-based status differences are suggested by variations in grave goods quantities and types at the prehistoric sites of Ban Non Wat, Noen U-Loke, and Nong Nor (Fig. 1) in northeast and central Thailand (Cekalovic 2014; Chang 2001). More recent material culture research in the region has focused on prehistoric mortuary artifacts as markers of identity and personhood (Cekalovic 2014; Heath 2017; Lim 2018). For example, specific ceramic types have been linked to adult and subadult age categories at Non Ban Jak, suggesting that age was symbolized through grave goods in late prehistory (Heath 2017; Lim 2018).

Turning to the historic period, inscriptions dating to A.D. 1500-1600 from Cambodia suggest that age was recognized in addition to social class (Ebihara 1984:294). A parallel is seen in earlier pre-Angkorian inscriptions (A.D. 600s), which recognize a number of social age groups among children (Vickery 1998). Together, these findings suggest that grave goods may

Table 5. Quantile regression: main effects model assessing how long bone lengths change between the sexes, east and west mounds, and over time while adjusting for the effects of each co-variable.

\begin{tabular}{|c|c|c|c|c|c|c|}
\hline Long Bone & $n$ Observed & Predictor & Level & Coefficient & $95 \%$ CI & $p$-value \\
\hline Femur & 25 & $\begin{array}{l}\text { Constant } \\
\text { Sex } \\
\text { Phase } \\
\text { Mound }\end{array}$ & $\begin{array}{l}\text { Early East Females }{ }^{\dagger} \\
\text { Male } \\
\text { Late } \\
\text { West }\end{array}$ & $\begin{array}{r}39.36 \\
3.63 \\
-0.23 \\
2.03\end{array}$ & $\begin{array}{r}36.58,42.14 \\
1.36,5.90 \\
-2.25,2.11 \\
-0.76,4.83\end{array}$ & $\begin{array}{r}<0.001 \\
\mathbf{0 . 0 0 3} \\
0.837 \\
0.146\end{array}$ \\
\hline Tibia & 19 & $\begin{array}{l}\text { Constant } \\
\text { Sex } \\
\text { Phase } \\
\text { Mound }\end{array}$ & $\begin{array}{l}\text { Early East Females }{ }^{\dagger} \\
\text { Male } \\
\text { Late } \\
\text { West }\end{array}$ & $\begin{array}{r}32.73 \\
4.29 \\
0.79 \\
2.27\end{array}$ & $\begin{array}{r}27.69,37.76 \\
1.35,7.24 \\
-2.19,3.79 \\
-2.53,7.07\end{array}$ & $\begin{array}{r}<0.001 \\
\mathbf{0 . 0 0 7} \\
0.577 \\
0.330\end{array}$ \\
\hline Humerus & 23 & $\begin{array}{l}\text { Constant } \\
\text { Sex } \\
\text { Phase } \\
\text { Mound }\end{array}$ & $\begin{array}{l}\text { Reference } \\
\text { Early East Females }{ }^{\dagger} \\
\text { Late } \\
\text { West }\end{array}$ & $\begin{array}{r}29.10 \\
2.00 \\
-0.53 \\
0.89\end{array}$ & $\begin{array}{r}26.86,31.33 \\
0.09,3.90 \\
-2.54,1.48 \\
-1.33,3.13\end{array}$ & $\begin{array}{r}<0.001 \\
\mathbf{0 . 0 4 1} \\
0.588 \\
0.410\end{array}$ \\
\hline Radius & 23 & $\begin{array}{l}\text { Constant } \\
\text { Sex } \\
\text { Phase } \\
\text { Mound }\end{array}$ & $\begin{array}{l}\text { Early East Females }{ }^{\dagger} \\
\text { Male } \\
\text { Late } \\
\text { West }\end{array}$ & $\begin{array}{r}22.05 \\
2.15 \\
-0.85 \\
1.94\end{array}$ & $\begin{array}{r}20.26,23.83 \\
0.67,3.62 \\
-2.40,0.70 \\
0.16,3.73\end{array}$ & $\begin{array}{r}<0.001 \\
\mathbf{0 . 0 0 6} \\
0.268 \\
\mathbf{0 . 0 3 4}\end{array}$ \\
\hline Ulna & 21 & $\begin{array}{l}\text { Constant } \\
\text { Sex } \\
\text { Phase } \\
\text { Mound }\end{array}$ & $\begin{array}{l}\text { Early East Females }{ }^{\dagger} \\
\text { Male } \\
\text { Late } \\
\text { West }\end{array}$ & $\begin{array}{r}24.33 \\
1.70 \\
0.40 \\
0.96\end{array}$ & $\begin{array}{r}22.92,25.73 \\
0.35,3.04 \\
-1.00,1.80 \\
-0.55,2.49\end{array}$ & $\begin{array}{r}<0.001 \\
\mathbf{0 . 0 1 6} \\
0.556 \\
0.196\end{array}$ \\
\hline
\end{tabular}

Key: $\mathrm{CI}=$ confidence interval. Bold values are statistically significant.

†The coefficient for the model constant is the median long bone length for early east mound females. 


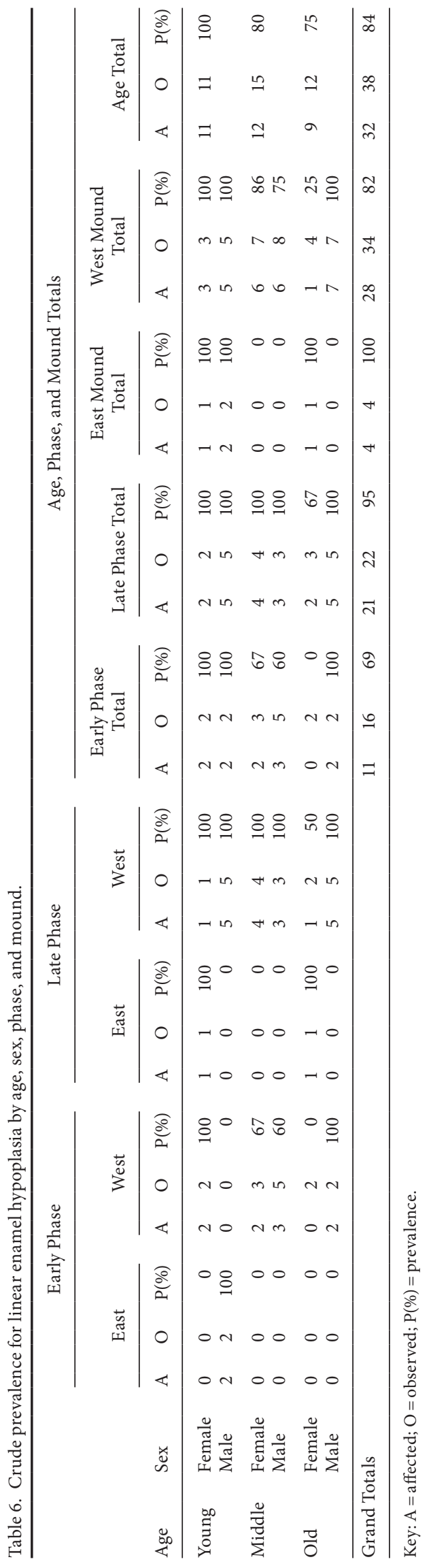


reflect the attainment of age-related milestones in prehistoric Southeast Asia, although recognition of milestones and the presence of inequality may not be mutually exclusive.

Females of all ages at Non Ban Jak received statistically significantly fewer grave items than males, suggesting a social difference between the sexes. Evidence of sex-based inequality has previously been identified at the Bronze Age site of Non Nok Tha, where males received increased quantities of grave goods and greater energy expenditure on burial rites over time (Bacus 2006). This trend continued into the Iron Age at Noen U-Loke, where females received fewer grave goods relative to males (Cekalovic 2014; Chang 2001).

In contrast, queens have been identified in the later pre-Angkorian period (A.D. 500-800), suggesting that women were active political players at this time (Andaya 1994, 2007; Jacobsen 2003). However, while land ownership was passed through the maternal line (Jacobsen 2003), the use of male titles and an emphasis on male ancestry was still required in order to legitimize female leadership (Jacobsen 2003; Vickery 1998). Royal manipulation of descent rules for personal gain throughout this period is likely to have created fluctuations in the relative statuses of males and females (Jacobsen 2003; Vickery 1998).

The adoption of Brahminism and Buddhism during the late Iron Age and pre-Angkorian period further encouraged the development of an increasingly patriarchal society (Andaya 1994; Jacobsen 2003:361-362). Buddhist ideologies were key to the development of the proto-Dvāravati (A.D. 300-400) and Dvāravati (A.D. 600-1000) cultures in central Thailand (Glover 2010; Murphy 2016) (Fig. 1), while both Brahminism and Buddhism were significant in Funan (A.D. 100$600)$ in the Mekong Delta and early Khmer polities in central Cambodia (Briggs 1999; Stark 2004; Terwiel 1975) (Fig. 1).

The presence of Buddhist icons in the upper layers of the east mound of Non Ban Jak and Dvāravati deposits at Muang Sema to the west of Non Ban Jak (Fig. 1) suggest contact between northeast and central Thailand in the pre-Angkorian period (Higham and Kijngam in press; Higham et al. 2019; Talbot and Janthed 2001). Contact between early Cambodia and northeast Thailand is also suggested through the presence of northeast Thai Phimai Black ceramics at the sites of Phum Sophy and Phum Snay in northwest Cambodia (Domett and O'Reilly 2009; O'Reilly et al. 2008).

The appearance of brick temples, inscriptions, and changing settlement patterns in northeast Thailand after this period of contact suggests a cultural transition in northeast Thailand, leading C. Evans et al. (2016) to argue that agrarian villages such as Non Ban
Jak may have been absorbed into regional polities to form supply centers. While the links between Non Ban Jak and epigraphic accounts of increasing patriarchy are tenuous, we hypothesize that contact between these polities and Non Ban Jak led to the adoption of new social ideologies for legitimizing sex-based status differences. However, more research is needed to test this theory and determine the nature, timing, and duration of these putative contacts.

This article has demonstrated that east mound individuals of all ages and sexes received significantly fewer grave goods than those from the west mound. This difference may reflect mortuary recognition of social differences between the mounds. Possible social differences are now explored, before presenting the argument for the presence of a class system at Non Ban Jak.

The spatial separation of east and west mound graves may reflect the spatial embodiment of differences in age, sex, ideology, and ethnicity as well as practical divisions of the living and the dead (Binford 1971; Goldstein 1981; Meskell 1998; Parker Pearson 1993, 1999; Ucko 1969). Segregation may also represent social exclusions related to class differences, or interactions of multiple factors outlined above (Delle 1998; Reidpath et al. 2005). However, spatial statistical analysis at Non Ban Jak has revealed no segregation of individuals based on age or sex, or health status (Ward 2019), and isotopic evidence has shown that very little migration of isotopically unique people occurred in northeast Thailand in the Iron Age. This suggests that Non Ban Jak is a genetically homogeneous population, although isotopic analysis does not exclude the possibility of migration of isotopically similar groups (Cox et al. 2011; Schalburg-Clayton et al. 2018). As such, the mounds are not likely to represent different populations.

As evidenced by inscriptions in inland Cambodia, polities containing distinct social classes existed concurrently with Non Ban Jak (Vickery 1998). These social classes are thought to have formed out of ranked lineage groups, with higher social status given to more senior family lines (Vickery 1998). Given the presence of class societies contemporaneous with Non Ban Jak and differences in grave goods quantities between the east and west mounds of this site, we argue that spatial differences between the east and west mounds of Non Ban Jak reflect a putative kinship-based class structure. It is hypothesized that residential burial provided a mechanism for the formation and legitimization of these social classes.

Residential burial and the presence of physical houses at Non Ban Jak are suggestive of social houses, which provide a lineage-based route for the transmission of wealth accrued through trade (Higham 
et al. 2019; O’Reilly 2014). Furthermore, house burials provide a means of claiming land through the interment of ancestors, suggesting the possibility of ownership of residential mound areas at the site. However, it is unclear whether these residential mound areas were owned by "houses" or "classes" and whether ownership extended to the surrounding agricultural land. No evidence for this (e.g., bunded rice fields) has been observed in prehistoric northeast Thailand to date, although bunded, irregularly oriented rice fields indicate that separate collective, yet private, land ownership existed in Iron Age Cambodia (Hawken 2013). It is clear that more research is needed on this compelling issue, particularly as control of agricultural areas may have provided a valuable pathway for wealth accrual.

\section{Exploring non-specific stress and its links to} social status at Non Ban Jak

Although growth disruptions leading to short stature and LEH occur as a result of childhood stress and cannot provide information on adult health, identification of variations in the prevalence of these stress indicators between adult age groups may provide information on short-term (e.g., generational) fluctuations in health within a population. Considered together, they may also provide insight into selective mortality and heterogeneity in frailty, which are among the key tenets of the osteological paradox (DeWitte and Stojanowski 2015). Therefore, differences in stress between adult age groups are briefly discussed.

The stress indicators investigated paint varying pictures of adult health at Non Ban Jak. Variation in stature is considered first. As noted above, the inhabitants of northeast Thailand are thought to represent a homogeneous population (Cox et al. 2011; SchalburgClayton et al. 2018). Analysis of stature at Non Ban Jak is therefore likely to reveal social, rather than biological, differences between age, sex, phase, and mound groups.

This study has demonstrated that young adults experienced increased variation in long bone lengths relative to older adults. According to recent bioarchaeological research, greater stress in a community may result in reduced variation in stature, as frail individuals who would typically become short adults are removed from the population through natural selection (DeWitte and Hughes-Morey 2012; Domett 2001; Hughes-Morey 2016; Vercellotti et al. 2014). As such, variation in long bone lengths may provide insight into selective pressures acting on a population. Following this argument, increased variation in stature among young adults at Non Ban Jak may be linked to reduced mortality risk during childhood. Stature variation may also be used as an indicator of social organization (e.g., Domett 2001). For example, Domett (2001) argues that low variation in stature reflects equal access to resources, which creates equal opportunity for all individuals to reach their genetic potential for stature. Therefore, reduced variation may reflect a more egalitarian social structure. However, to affect childhood health, status must be inherited. Where status is achieved over time, it is likely that all young individuals would receive similar treatment in childhood and that stature variation would result from variation in frailty and selective mortality, rather than differences in status.

However, consideration of LEH evidence alongside stature suggests a contrasting perspective. The higher prevalence of LEH observed among young adults indicates increased early life exposure to stress. When stature is reinterpreted in the context of high subadult mortality and prevalent LEH at Non Ban Jak, it is likely that in the increased variation in stature may paradoxically represent conditions of high mortality (Wood et al. 1992). Furthermore, LEH has been linked to lowered life expectancy, particularly in young adults and males (Boldsen 2007; DeWitte and Wood 2008; Palubeckaite et al. 2002; Steckel 2005). The fact that these individuals died as young adults may therefore be reflective of selective mortality, and as such, childhood stress burdens may have been higher among this age group (DeWitte and Stojanowski 2015; Wood et al. 1992). This suggests the presence of short-term fluctuations in stress levels between generations at Non Ban Jak.

Patterns of age at death, LEH prevalence, and stature provide conflicting information regarding stress levels among the sexes. Results showed that female mortality reduced over time, stature decreased, and LEH prevalence decreased, while males showed the opposite trends. Two interpretations may be drawn from this information and are discussed below.

A number of researchers have argued that males experience higher mortality risk and reduced survivorship compared to females, suggesting that an interpretation of greater male stress may be more applicable to Non Ban Jak (Eveleth 1975; Stini 1969; Stinson 1985; Tobias 1975). The first possible interpretation builds on this argument: High levels of mortality among the males may reflect inherent frailty exacerbated by exposure to physiological stress. Increases in adult male stature are therefore paradoxically attributed to high mortality in childhood, which removed frail short individuals prior to their reaching adulthood and entering the adult sample (e.g., Wood et al. 1992). This interpretation accords with the stressful childhood environment suggested by the high prevalence of LEH among the males. However, this perspective is challenged by the fact that many male individuals still survived to form defects and to reach 
adulthood, suggesting moderate robusticity among the males from the site.

The second possible interpretation draws on the osteological paradox, arguing that females may have experienced social disadvantage that increased their frailty. Here we argue that low mortality among females may be a product of selective mortality, as the frailest individuals would have died in childhood, reducing mortality risk in adulthood (Wood et al. 1992). The purported higher mortality among the females suggests that fewer females would have lived long enough during childhood to form LEH (Hillson and Bond 1997), which may explain the reduced LEH prevalence observed among the Non Ban Jak females. More robust female individuals who survived childhood may have been unable to reach their genetic potential for stature due to inadequate conditions for growth during development, reducing female stature (Bogin 1999; Eveleth and Tanner 1991; Stinson 2012).

High neonatal mortality rates at the site also provide support for this argument (Table 1). Deaths in the neonatal period (0-1 month postpartum) are attributed to high maternal stress, which clinical studies have demonstrated results in higher rates of pre-term birth and neonatal and maternal mortality (Austin and Leader 2000; Bourgeois-Pichat 1951; Dole et al. 2003; Lewis and Gowland 2007; S. Scott and Duncan 1999). Therefore, female stress burdens at Non Ban Jak are likely to have been high relative to those of the males. An increased prevalence of pre-term births and infant, maternal, and adult mortality is seen among low-status individuals in modern populations (Adler et al. 1994; Di Cesare et al. 2013; Kawachi and Kennedy 1999; Marmot 2005; Morello-Frosch and Shenassa 2006; Siegrist and Marmot 2006). This supports the suggestion of lower social status among the Non Ban Jak females made above and suggests that low status had a negative effect on health among these members of the Non Ban Jak community.

The small sample sizes involved in this study make differences in non-specific stress between the east and west mounds difficult to discern, and the following interpretations are offered with caution. Results showed that west mound individuals, interred with greater quantities of grave goods, had taller stature, a lower prevalence of LEH, and reduced subadult mortality $(66.11 \%, 41 / 121)$ relative to the east mound individuals $(85 \%, 34 / 40)$, suggesting that they represent a less stressed portion of the community. In contrast, the east mound may represent the more impoverished, and more stressed, members of the community. While the most robust individuals in the east mound survived into adulthood, they appear to have been unable to recover from childhood stress, represented by reduced stature relative to the west mound adults.
However, an alternative interpretation for the mound differences in non-specific stress is possible. Paradoxically, shorter stature may indicate decreasing stress in a population (Costa 2012; Hughes-Morey 2016; Wood et al. 1992). This suggests that the shorterstatured east mound may have suffered less stress. However, this argument does not account for stressrelated increases in frailty among survivors, which have the effect of increasing mortality risk even under normal conditions (DeWitte and Hughes-Morey 2012; DeWitte and Wood 2008; Yaussy and DeWitte 2018; Yaussy et al. 2016). In addition, paradoxical views are negated by the high levels of subadult mortality and greater prevalence of LEH in the east mound (Buckley et al. in press), which suggest high stress in early childhood. Given the conditions of stress, the reduced mortality seen among east mound adults is likely to be an illusion created by selective mortality (Wood et al. 1992). This interpretation of greater stress in the east mound accords with established inequality literature, which demonstrates that lower social status is associated with poorer health (Dahl et al. 2006; Dunn and Hayes 2000; Kawachi and Kennedy 1997, 1999; Leon et al. 1992; Murali and Oyebode 2004; Pickett and Wilkinson 2015; Siegrist and Marmot 2006; Wilkinson and Pickett 2009).

Differences in stress burdens between the mounds may represent the different social roles of the putative classes at Non Ban Jak, varying exposure to disease environments as a result of these roles, and statusbased buffering of stress. Analysis of skeletal trauma at Non Ban Jak demonstrates a higher prevalence of injuries related to agricultural activity in the east mound, suggesting that east mound individuals represent an agricultural laborer class (Pedersen et al. 2019). The transition to wet rice agriculture itself is also likely to have had severe repercussions on health, including providing habitats (e.g., rice paddies) for colonization by parasites and their vectors (Halcrow et al. 2016; Higham et al. 2019; King et al. 2017). While certain risks would likely be common to all inhabitants of Non Ban Jak (e.g., exposure to parasites in food), individuals undertaking agricultural activities potentially suffered greater exposure to these pathogens via their occupation. Furthermore, evidence for animal husbandry in this period suggests the possibility of zoonotic transfer of infectious diseases though ingestion of contaminated animal products and exposure to cough spray among agricultural workers (e.g., Cosivi et al. 1998).

In contrast, disease profiles observed among the inhabitants of the west mound may relate to greater disease exposure through trade, as proposed for the presence of leprosy and tuberculosis at Noen U-Loke (Tayles and Buckley 2004). A preliminary analysis of pathology at Non Ban Jak has indicated the presence 
of at least two possible cases of leprosy and nine cases of possible tuberculosis, all but one of which are found in west mound individuals (Buckley et al. in press).

To summarize, evidence for variation in grave goods quantities by sex and mound suggests the presence of status differentiation at Non Ban Jak, while variation in stress suggests that the site's inhabitants experienced variable health based on social identity. Gendered divisions of labor, diet, and health have previously been identified elsewhere in the region, suggesting that the foundations of unequal societies may have been established earlier and built upon in the Iron Age (Douglas 1996; Newton et al. 2013; Pietrusewsky and Douglas 2002).

\section{Conclusion}

This article presents an assessment of the relationship between social status and health in prehistoric northeast Thailand. This assessment, limited previously by poor bone preservation in the Iron Age of Southeast Asia, is one of very few focusing on health and status in this region and time period. We have demonstrated, on the basis of a grave goods analysis, that there may be sex- and class-related status differences at Non Ban Jak. Previous archaeological studies and epigraphic evidence support these interpretations, demonstrating the presence of sex and class differentiation in prehistoric and historic Southeast Asia, while the concept of a house society may provide a mechanism for the development of a class society at the site. The analysis of non-specific stress indicators suggests that stress burdens varied according to social identity and social status and that low social status relates to poorer health in this community.

\section{Acknowledgments}

This research has been funded by the Australian Research Council (DP110101997), the Royal Society of New Zealand Marsden Fund and a University of Otago Research Grant. SW was funded by a University of Otago Doctoral Scholarship, a University of Otago Department of Anatomy Departmental Award, and a University of Otago Publishing Bursary. We wish to thank the Fine Arts Department of Thailand, the National Research Council of Thailand, the villagers of Ban Non Wat and Ban Non Khrua Chut, Nigel Chang, Nathan Harris, Pimpicha Bannanurak, Rachanie Thosarat, Chanakarn Hongtong, Samur Thongsooknork, Helen Heath, Christina Stantis, and the team of volunteers for their support in undertaking this research. We also thank
Thanik Lertcharnrit for providing the Thai language translation of the abstract.

\section{Supplemental Materials}

Supplemental tables may be found online with the electronic version of the article.

\section{References}

Adler, Nancy E., Thomas Boyce, Margaret A. Chesney, Sheldon Cohen, Susan Folkman, Robert L. Kahn, and S. Leonard Syme. 1994. Socioeconomic status and health: The challenge of the gradient. American Psychologist 49(1):15-24. DOI: 10.1037/0003 -066X.49.1.15.

Ames, Kenneth M. 2008. The archaeology of rank. In Handbook of Archaeological Theories, edited by R. Alexander Bentley, Herbert D. G. Maschner and Christopher Chippindale. AltaMira Press, Lanham, pp. 487-513.

Andaya, Barbara Watson. 1994. The changing religious role of women in pre-modern South East Asia. South East Asia Research 2(2):99-116. DOI: https://www.jstor.org/stable/23746860.

Andaya, Barbara Watson. 2007. Studying women and gender in Southeast Asia. International Journal of Asian Studies 4(1): 113-136. DOI: 10.1017/S147959140700054X.

Austin, Marie-Paule, and Leo Leader. 2000. Maternal stress and obstetric and infant outcomes: Epidemiological findings and neuroendocrine mechanisms. Australian and New Zealand Journal of Obstetrics and Gynaecology 40(3):331-337. DOI: 10 $.1111 /$ j.1479-828X.2000.tb03344.x.

Bacus, Elisabeth A. 2006. Social identities in Bronze Age northeast Thailand: Interactions of gender, status and ranking at Non Nok Tha. In Uncovering Southeast Asia's Past: Selected Papers from the 10th International Conference of the European Association of Southeast Asian Archaeologists, edited by Elisabeth A. Bacus, Ian C. Glover, and Vincent C. Piggott. NUS Press, Singapore, pp. 105-115.

Bayard, Donn. 1984. Rank and wealth at Non Nok Tha: The mortuary evidence. In Southeast Asian Archaeology at the XV Pacific Science Congress: Papers Presented in Symposium K.1.e, the Origins of Argriculture, Metallurgy, and the State of Mainland Southeast Asia., edited by Donn T. Bayard. University of Otago Department of Anthropology, Dunedin, NZ, pp. 87-122.

Binford, Lewis R. 1971. Mortuary practices: Their study and their potential. Memoirs of the Society for American Archaeology 25:6-29. DOI: https://www.jstor.org/stable/25146709.

Bogin, Barry. 1999. Patterns of Human Growth. Cambridge University Press, Cambridge.

Boldsen, Jesper L. 2007. Early childhood stress and adult age mortality: A study of dental enamel hypoplasia in the medieval Danish village of Tirup. American Journal of Physical Anthropology 132(1):59-66. DOI: 10.1002/ajpa.20467.

Bourgeois-Pichat, Jean. 1951. La measure de la mortalité infantile: I. Principes et méthodes. Population 6(2):233-248.

Briggs, Lawrence Palmer. 1999. The Ancient Khmer Empire. White Lotus Press, Bangkok.

Brooks, Sheilagh, and Judy M. Suchey. 1990. Skeletal age determination based on the os pubis: A comparison of the AcsádiNemeskéri and Suchey-Brooks methods. Human Evolution 5(3):227-238. DOI: 10.1007/bf02437238.

Brown, James A. 1995. On mortuary analysis-with special reference to the Saxe-Binford research program. In Regional 
Approaches to Mortuary Analysis, edited by Lane Anderson Beck. Springer Science and Business Media, New York, pp. 3-28.

Brunner, Eric. 1997. Socioeconomic determinants of health: Stress and the biology of inequality. British Medical Journal 314:1472. DOI: $10.1136 /$ bmj.314.7092.1472.

Bruzek, Jaroslav. 2002. A method for visual determination of sex, using the human hip bone. American Journal of Physical Anthropology 117(2):157-168. DOI: 10.1002/ajpa.10012.

Buckley, Hallie R., Kate M. Domett, Siân E. Halcrow, Lucille T. Pedersen, Stacey M. Ward, Nellissa Ling, Dougald J. W. O’Reilly and Louise Shewan. In press. An initial report on health and disease at Non Ban Jak. In The Origins of Angkor Volume VII: The Excavation of Non Ban Jak, edited by Charles F. W. Higham and Amphan Kijngam. The Fine Arts Department of Thailand, Bangkok.

Buikstra, Jane E., and Douglas H. Ubelaker. 1994. Standards for Data Collection from Human Skeletal Remains. Arkansas Archaeological Survey Research Report No. 44, Fayetteville.

Cares Henriquez, Alejandra, and Marc F. Oxenham. 2017. An alternative objective microscopic method for the identification of linear enamel hypoplasia (LEH) in the absence of visible perikymata. Journal of Archaeological Science: Reports 14: 76-84. DOI: 10.1016/j.jasrep.2017.05.040.

Cares Henriquez, Alejandra, and Marc F. Oxenham. 2019. New distance-based exponential regression method and equations for estimating the chronology of linear enamel hypoplasia (LEH) defects on the anterior dentition. American Journal of Physical Anthropology 168(3):510-520. DOI: 10.1002/ajpa.23764.

Castillo, Cristina C., Charles F. W. Higham, Katie Miller, Nigel Chang, Katerina Douka, Thomas F. G. Higham, and Dorian Q. Fuller. 2018. Social responses to climate change in Iron Age north-east Thailand: New archaeobotanical evidence. Antiquity 92(365):1274-1291. DOI: 10.15184/aqy.2018.198.

Cekalovic, Helen. 2014. Health and Society in Southeast Asia: The Transition from the late Bronze Age to Iron Age. Ph.D. dissertation, James Cook University. Research Online@JCU, Townsville, Australia.

Chang, Nigel. 2001. Personal Ornaments in Thai History: Nong Nor, Ban Lum Khao and Noen U-Loke. Ph.D. dissertation, University of Otago. Otago University Research Archive, Dunedin, New Zealand.

Chapman, Robert. 2013. Death, burial, and social reprentatation. In The Oxford Handbook of the Archaeology of Death and Burial, edited by Sarah Tarlow and Liv Nilsson Stutz. Oxford University Press, Oxford, pp. 47-58.

Chawchai, Sakonvan, Akkaneewut Chabangborn, Sherilyn Fritz, Minna Väliranta, Carl-Magnus Mörth, Maarten Blaauw, Paula J. Reimer, Paul J. Krusic, Ludvig Löwemark, and Barbara Wohlfarth. 2015a. Hydroclimatic shifts in northeast Thailand during the last two millennia: The record of Lake Pa Kho. Quaternary Science Reviews 111:62-71. DOI: 10.1016/j.quascirev .2015.01.007.

Chawchai, Sakonvan, Kweku Afrifa Yamoah, Rienk H. Smittenberg, Janita Kurkela, Minna Väliranta, Akkaneewut Chabangborn, Maarten Blaauw, Sherilyn C. Fritz, Paula J. Reimer, and Barbara Wohlfarth. 2015b. Lake Kumphawapi revisited: The complex climatic and environmental record of a tropical wetland in NE Thailand. The Holocene 26(4):614-626. DOI: 10.1177 /0959683615612565.

Clark, Angela L., Nancy Tayles, and Siân E. Halcrow. 2014. Aspects of health in prehistoric mainland Southeast Asia: Indicators of stress in response to the intensification of rice agriculture. American Journal of Physical Anthropology 153:484-495. DOI: 10.1002/ajpa.22449.

Cosivi, Ottorino, John M. Grange, Chris J. Daborn, Mario C. Raviglione, T. Fujikura, Deb V. Cousins, R. A. Robinson, H. F.
Huchzermeyer, Isabel de Kantor, and François-Xavier Meslin. 1998. Zoonotic tuberculosis due to Mycobacterium bovis in developing countries. Emerging Infectious Diseases 4(1):59-70. DOI: 10.3201/eid0401.980108.

Costa, Dora L. 2012. Scarring and mortality selection among Civil War POWs: A long-term mortality, morbidity, and socioeconomic follow-up. Demography 49(4):1185-1206. DOI: 10.1007 /s13524-012-0125-9.

Cox, Katharine J., R. Alexander Bentley, Nancy Tayles, Hallie R. Buckley, Colin G. Macpherson, and Matthew J. Cooper. 2011. Intrinsic or extrinsic population growth in Iron Age northeast Thailand? The evidence from isotopic analysis. Journal of Archaeological Science 38(3):665-671. DOI: 10.1016/j.jas.2010.10 .018 .

Crass, Barbara A. 2001. Gender and mortuary analysis: What can grave goods really tell us? In Gender and the Archaeology of Death, edited by Bettina Arnold and Nancy L. Wicker. AltaMira Press, Lanham, MD, pp. 105-118.

Dahl, Espen, Jon Ivar Elstad, Dag Hofoss, and Melissa MartinMollard. 2006. For whom is income inequality most harmful? A multi-level analysis of income inequality and mortality in Norway. Social Science \& Medicine 63(10):2562-2574. DOI: 10 .1016/j.socscimed.2006.06.002.

Delle, James A. 1998. An Archaeology of Social Space: Analyzing Coffee Plantations in Jamaica's Blue Mountains. Plenum Press, New York.

DeWitte, Sharon N., and Gail Hughes-Morey. 2012. Stature and frailty during the Black Death: The effect of stature on risks of epidemic mortality in London, A.D. 1348-1350. Journal of Archaeological Science 39(5):1412-1419. DOI: 10.1016/j.jas.2012.01 .019 .

DeWitte, Sharon N., and Chistopher M. Stojanowski. 2015. The osteological paradox 20 years later: Past perspectives, future directions. Journal of Archaeological Research 23(4):397-450. DOI: 10.1007/s10814-015-9084-1.

DeWitte, Sharon N., and James W. Wood. 2008. Selectivity of Black Death mortality with respect to preexisting health. Proceedings of the National Academy of Sciences 105(5):1436-1441. DOI: $10.1073 /$ pnas.0705460105.

Di Cesare, Mariachiara, Young-Ho Khang, Perviz Asaria, Tony Blakely, Melanie J. Cowan, Farshad Farzadfar, Ramiro Guerrero, Nayu Ikeda, Catherine Kyobutungi, Kelias P. Msyamboza, Sophal Oum, John W. Lynch, Michael G. Marmot, and Majid Ezzati. 2013. Inequalities in non-communicable diseases and effective responses. The Lancet 381(9866):585-597. DOI: 10 $.1016 /$ S0140-6736(12)61851-0.

Dole, Nancy, David A. Savitz, Irva Hertz-Picciotto, Anna M. Siega-Riz, Michael J. McMahon, and Pierre Buekends. 2003. Maternal stress and preterm birth. American Journal of Epidemiology 157(1):14-24. DOI: 10.1093/aje/kwf176.

Domett, Kathryn M. 2001. Health in Late Prehistoric Thailand. BAR International Series 946. Archaeopress, Oxford.

Domett, Kate M., and Dougald J. W. O'Reilly. 2009. Health in preAngkorian Cambodia: A bioarchaeological analysis of the skeletal remains from Phum Snay. Asian Perspectives 48(1):5678. DOI: https://www.jstor.org/stable/42928753.

Domett, Kate M., Dougald J. W. O’Reilly, and Hallie R. Buckley. 2011. Bioarchaeological evidence for conflict in Iron Age northwest Cambodia. Antiquity 85(328):441-458. DOI: 10.1017/S000 $3598 X 00067867$.

Douglas, Michele T. 1996. Paleopathology in Human Skeletal Remains from the Pre-metal, Bronze, and Iron Ages, Northeastern Thailand. Ph.D. dissertation, University of Hawai' $i$, Honolulu. University Microfilms, Ann Arbor.

Dunn, James R., and Michael V. Hayes. 2000. Social inequality, population health, and housing: A study of two Vancouver 
neighborhoods. Social Science \& Medicine 51(4):563-587. DOI: 10.1016/S0277-9536(99)00496-7.

Earle, Timothy K. 1987. Chiefdoms in archaeological and ethnohistorical perspective. Annual Review of Anthropology 16:279308. DOI: http://www.jstor.org/stable/2155873.

Ebihara, May. 1984. Societal organization in sixteenth and seventeenth century Cambodia. Journal of Southeast Asian Studies 15(2):280-295. DOI: 10.1017/S0022463400012522.

Ekengren, Fredrik. 2013. Contextualising grave goods: Theoretical perspectives and methodological implications. In The $O x-$ ford Handbook of the Archaeology of Death and Burial, edited by Sarah Tarlow and Liv Nilsson Stutz. Oxford University Press, Oxford, pp. 173-192.

Evans, Caitlin, Nigel Chang, and Naho Shimizu. 2016. Sites, survey, and ceramics: Settlement patterns of the first to ninth centuries CE in the Upper Mun River Valley, northeast Thailand. Journal of Southeast Asian Studies 47(3):438-467. DOI: 10.1017 /S0022463416000278.

Evans, Gary W., and Pilyoung Kim. 2013. Childhood poverty, chronic stress, self-regulation, and coping. Child Development Perspectives 7(1):43-48. DOI: 10.1111/cdep.12013.

Eveleth, Phyllis B. 1975. Differences between ethnic groups in sex dimorphism of adult height. Annals of Human Biology 2(1):3539. DOI: $10.1080 / 03014467500000541$.

Eveleth, Phyllis B., and James M. Tanner. 1991. Worldwide Variation in Human Growth. Cambridge University Press, Cambridge.

Fédération Dentaire Internationale. 1982. An epidemiological index of developmental defects of dental enamel (DDE Index). International Dental Journal 32(2):159-167.

Feinman, Gary M. 1995. The emergence of inequality: A focus on strategies and processes. In Foundations of Social Inequality, edited by T. Douglas Price and Gary M. Feinman. Springer, New York, pp. 255-280.

Foster, Aimee V. 2011. Gendered Divisions of Labour in Southeast Asian and Pacific Island Prehistory. Ph.D. dissertation, University of Otago. Otago University Research Archive, Dunedin, New Zealand.

Fowler, Chris. 2013. Identities in transformation: Identities, funerary rites, and the mortuary process. In The Oxford Handbook of the Archaeology of Death and Burial, edited by Sarah Tarlow and Liv Nilsson Stutz. Oxford University Press, Oxford, pp. 511-526.

Gillespie, Susan D. 2000. Lévi-Strauss: Maison and sociéte à maisons. In Beyond Kinship: Social and Material Reproduction in House Societies, edited by Rosemary A. Joyce and Susan D. Gillespie. University of Pennyslvania Press, Philadelphia, pp. $22-52$.

Gillespie, Susan D. 2001. Personhood, agency, and mortuary ritual: A case study from the ancient Maya. Journal of Anthropological Archaeology 20(1):73-112. DOI: 10.1006/jaar.2000.0369.

Glover, Ian. 2010. The Dvaravati gap: Linking prehistory and history in early Thailand. Bulletin of the Indo-Pacific Prehistory Association 30:79-86. DOI: 10.7152/bippa.v30i0.10809.

Goldstein, Lynne. 1981. One-dimensional archaeology and multidimensional people: Spatial organisation and mortuary analysis. In The Archaeology of Death, edited by Robert W. Chapman, Ian Kinnes, and Klavs Randsborg. Cambridge University Press, Cambridge, pp. 53-69.

González-Ruibal, Alfredo. 2006. House societies vs. kinshipbased societies: An archaeological case from Iron Age Europe. Journal of Anthropological Archaeology 25(1):144-173. DOI: 10 .1016/j.jaa.2005.09.002.

Goodman, Alan H., and George J. Armelagos. 1988. Childhood stress and decreased longevity in a prehistoric population. American Anthropologist 90(4):936-944. DOI: 10.1525/aa.1988 $.90 .4 .02 \mathrm{a} 00120$.
Goodman, Alan H., and George J. Armelagos. 1989. Infant and childhood morbidity and mortality risks in archaeological populations. World Archaeology 21(2):225-243. DOI: 10.1080 /00438243.1989.9980103.

Goodman, Alan H., George J. Armelagos, and Jerome C. Rose. 1980. Enamel hypoplasias as indicators of stress in three prehistoric populations from Illinois. Human Biology 52(3):515528. DOI: $10.1177 / 08959374890030022801$.

Goodman, Alan H., and Jerome C. Rose. 1990. Assessment of systemic physiological perturbations from dental enamel hypoplasias and associated histological structures. American Journal of Physical Anthropology 33(S11):59-110. DOI: 10.1002 /ajpa.1330330506.

Goodman, Alan H., and Jerome C. Rose. 1991. Dental enamel hypoplasias as indicators of nurtitional status. In Advances in Dental Anthropology, edited by Mark A. Kelley and Clark Spencer Larsen. Wiley-Liss, New York, pp. 279-293.

Halcrow, Siân E., Nancy Tayles, and Charlotte L. King. 2016. Infant and child health and disease with agricultural intensification in mainland Southeast Asia. In The Routledge Handbook of Bioarchaeology in Southeast Asia and the Pacific Islands, edited by Marc Oxenham and Hallie R. Buckley. Routledge, Abingdon, UK, pp. 158-186.

Halcrow, Siân E., Nancy Tayles, and Vicki Livingstone. 2008. Infant death in late prehistoric Southeast Asia. Asian Perspectives 47(2):371-404. DOI: 10.1353/asi.0.0007.

Hawken, Scott. 2013. Designs of kings and farmers: Landscape systems of the Greater Angkor urban complex. Asian Perspectives 52(2):347-367. DOI: 10.1353/asi.2013.0010.

Hayden, Brian. 2001. The dynamics of wealth and poverty in the transegalitarian societies of Southeast Asia. Antiquity 75(289):571-581. DOI: 10.1017/S0003598X00088803.

Heath, Helen R. 2017. Phimai is the New Black: Assessing the Standardisation of Kiln Fired Phimai Black Ceramics from the Iron Age Site of Non Ban Jak, Northeast Thailand. MA dissertation, University of Otago, Otago University Research Archive, Dunedin, New Zealand.

Higham, Charles F. W. 2011. The Iron Age of the Mun Valley, Thailand. The Antiquaries Journal 91:101-144. DOI: 10.1017 /S0003581511000114.

Higham, Charles F. W. 2012. The long and winding road that leads to Angkor. Cambridge Archaeological Journal 22(2):265-289. DOI: $10.1017 /$ S0959774312000261.

Higham, Charles F. W. 2014. From the Iron Age to Angkor: New light on the origins of a state. Antiquity 88(341):822-835. DOI: 10.1017/S0003598X00050717.

Higham, Charles F. W. 2015. From site formation to social structure in prehistoric Thailand. Journal of Field Archaeology 40(4):383-396. DOI: 10.1179/2042458214Y.0000000010.

Higham, Charles F. W. 2016. At the dawn of history: From Iron Age aggrandisers to Zhenla kings. Journal of Southeast Asian Studies 47(3):418-437. DOI: 10.1017/S0022463416000266.

Higham, Charles F. W., Judith Cameron, Nigel Chang, Cristina Castillo, Siân Halcrow, Dougald O'Reilly, Fiona Petchey, and Louise Shewan. 2014. The excavation of Non Ban Jak, northeast Thailand: A report on the first three seasons. Journal of Indo-Pacific Archaeology 34:1-41. DOI: 10.7152/jipa.v34i0.14721.

Higham, Charles F. W., and Amphan Kijngam, eds. 2012. The Origins of the Civilization of Angkor Volume V: The Excavation of Ban Non Wat. Part Three: The Bronze Age. The Fine Arts Department of Thailand, Bangkok.

Higham, Charles F. W., and Amphan Kijngam, eds. In press. The Origins of Angkor Volume VII: The Excavation of Non Ban Jak. The Fine Arts Department of Thailand, Bankgok.

Higham, Charles F. W., Brian F. J. Manly, Rachanie Thosarat, Hallie R. Buckley, Nigel Chang, Siân E. Halcrow, Stacey M. 
Ward, Dougald J. W. O'Reilly, Louise G. Shewan, and Kate M. Domett. 2019. Environmental and social change in northeast Thailand during the Iron Age. Cambridge Archaeological Journal 29(4):549-569. DOI: 10.1017/S0959774319000192.

Higham, Charles F. W., and Fiorella Rispoli. 2014. The Mun Valley and central Thailand in prehistory: Integrating two cultural sequences. Open Archaeology 1:2-28. DOI: 10.2478/opar-2014-0002.

Hillson, Simon. 2005. Teeth. 2nd ed. Cambridge University Press, Cambridge.

Hillson, Simon. 2014. Tooth Development in Human Evolution and Bioarchaeology. Cambridge University Press, Cambridge.

Hillson, Simon, and Sandra Bond. 1997. Relationship of enamel hypoplasia to the pattern of tooth crown growth: A discussion. American Journal of Physical Anthropology 104(1):89-103. DOI: 10.1002/(SICI)1096-8644(199709)104:1<89::AID-AJPA6>3.0 .CO;2-8.

Hodder, Ian. 1982. Theory and Practice in Archaeology. Routledge, London.

Hughes-Morey, Gail. 2016. Interpreting adult stature in industrial London. American Journal of Physical Anthropology 159(1):126134. DOI: 10.1002/ajpa.22840.

Ikehara-Quebral, Rona M., Miriam T. Stark, William Belcher, Voeun Vuthy, John Krigbaum, R. Alexander Bentley, Michele Toomay Douglas, and Michael Pietrusewsky. 2017. Biocultural practices during the transition to history at the Vat Komnou Cemetery, Angkor Borei, Cambodia. Asian Perspectives 56(2):191-236. DOI: 10.1353/asi.2017.0008.

İșcan, M. Yaşar, Susan R. Loth, and Ronald K. Wright. 1984. Metamorphosis at the sternal rib end: A new method to estimate age at death in white males. American Journal of Physical Anthropology 65(2):147-156. DOI: 10.1002/ajpa.1330650206.

İşcan, M. Yaşar, Susan R. Loth, and Ronald K. Wright. 1985. Age estimation from the rib by phase analysis: White females. Journal of Forensic Science 30(3):853-863. DOI: 10.1520/JFS11018J.

Jacobsen, Trudy. 2003. Autonomous queenship in Cambodia, 1st-9th centuries AD. Journal of the Royal Asiatic Society 13(3):357-375. DOI: 10.1017/S1356186303003420.

Jantz, Richard L., David R. Hunt, and Lee Meadows. 1994. Maximum length of the tibia: How did Trotter measure it? American Journal of Physical Anthropology 93(4):525-528. DOI: 10 .1002/ajpa.1330930410.

Kawachi, Ichiro, and Bruce P. Kennedy. 1997. Health and social cohesion: Why care about income inequality? BMJ: British Medical Journal 314(7086):1037-1040. DOI: 10.1136/bmj.314 .7086.1037.

Kawachi, Ichiro, and Bruce P. Kennedy. 1999. Income inequality and health: Pathways and mechanisms. Health Services Research 34(1 Pt 2):215-227. DOI: https://www.ncbi.nlm.nih.gov /pmc/articles/PMC1088996/.

Kim, Hae-Young. 2017. Statistical notes for clinical researchers: Chi-squared test and Fisher's exact test. Restorative Dentistry \& Endodontics 42(2):152-155. DOI: 10.5395/rde.2017.42.2.152.

King, Charlotte L., R. Alexander Bentley, Charles Higham, Nancy Tayles, Una Strand Viðarsdóttir, Robert Layton, Colin G. Macpherson, and Geoff Nowell. 2014. Economic change after the agricultural revolution in Southeast Asia? Antiquity 88(339):112-125. DOI: 10.1017/S0003598X00050250.

King, Charlotte L., Siân E. Halcrow, Nancy Tayles, and Stephanie Shkrum. 2017. Considering the palaeoepidemiological implications of socioeconomic and environmental change in Southeast Asia. Archaeological Research in Asia 11(Supplement C): 27-37. DOI: 10.1016/j.ara.2017.05.003.

Koo, Terry K., and Mae Y. Li. 2016. A guideline of selecting and reporting intraclass correlation coefficients for reliability research. Journal of Chiropractic Medicine 15(2):155-163. DOI: 10 $.1016 /$ j.jcm.2016.02.012.
Leatherman, Thomas, and Kasey Jernigan. 2014. The reproduction of poverty and poor health in the production of health disparities in southern Peru. Annals of Anthropological Practice 38(2):284-299. DOI: 10.1111/napa.12057.

Leon, David A., Denny Vågerö, and Petra O. Olausson. 1992. Social class differences in infant mortality in Sweden: Comparison with England and Wales. BMJ: British Medical Journal 305(6855):687-691. DOI: 10.1136/bmj.305.6855.687.

Lewis, Mary E., and Rebecca Gowland. 2007. Brief and precarious lives: Infant mortality in contrasting sites from medieval and post-medieval England (AD 850-1859). American Journal of Physical Anthropology 134(1):117-129. DOI: 10.1002/ajpa .20643.

Lim, T. Siang. 2018. Thinking outside the "pot": The chaînes opératoires of prehistoric ceramics in northwest Cambodia. Paper presented at the 21st Congress of the Indo-Pacific Prehistory Association, Hue, Vietnam.

Littleton, Judith. 2005. Invisible impacts but long-term consequences: Hypoplasia and contact in central Australia. American Journal of Physical Anthropology 126(3):295-304. DOI: 10 .1002/ajpa.20054.

Lovejoy, C. Owen, Richard S. Meindl, Thomas R. Pryzbeck, and Robert P. Mensforth. 1985. Chronological metamorphosis of the auricular surface of the ilium: A new method for the determination of adult skeletal age at death. American Journal of Physical Anthropology 68(1):15-28. DOI: 10.1002/ajpa.133068 0103.

Lynch, John W., Susan A. Everson, George A. Kaplan, Riitta Salonen, and Jukka T. Salonen. 1998. Does low socioeconomic status potentiate the effects of heightened cardiovascular responses to stress on the progression of carotid atherosclerosis? American Journal of Public Health 88(3):389-394.

Marmot, Michael. 2005. Social determinants of health inequalities. The Lancet 365(9464):1099-1104. DOI: 10.1016/S0140-6736 (05)71146-6.

Marmot, Michael. 2006. Health in an unequal world: Social circumstances, biology and disease. Clinical Medicine 6(6):559572. DOI: 10.7861/clinmedicine.6-6-559.

Mays, Simon, Rachel Ives, and Megan Brickley. 2009. The effects of socioeconomic status on endochondral and appositional bone growth, and acquisition of cortical bone in children from 19th century Birmingham, England. American Journal of Physical Anthropology 140(3):410-416. DOI: 10.1002/ajpa.21076.

Meskell, Lynn. 1998. An archaeology of social relations in an Egyptian village. Journal of Archaeological Method and Theory 5(3):209-243. DOI: 10.1007/BF02428070.

Morello-Frosch, Rachel, and Edmond D. Shenassa. 2006. The environmental "riskscape" and social inequality: Implications for explaining maternal and child health disparities. Environmental Health Perspectives 114(8):1150-1153. DOI: 10.1289/ehp .8930 .

Morgan, Charity J. 2017. Use of proper statistical techniques for research studies with small samples. American Journal of Physiology-Lung, Cellular, and Molecular Physiology 313(5): L873-L877. DOI: 10.1152/ajplung.00238.2017.

Murali, Vijaya, and Femi Oyebode. 2004. Poverty, social inequality and mental health. Advances in Psychiatric Treatment 10(3):216-224. DOI: 10.1192/apt.10.3.216.

Murphy, Stephen A. 2016. The case for proto-Dvāravatī: A review of the art historical and archaeological evidence. Journal of Southeast Asian Studies 47(3):366-392. DOI: 10.1017/S00 22463416000242.

Newton, Jennifer S., Kate M. Domett, Dougald J. W. O'Reilly, and Louise Shewan. 2013. Dental health in Iron Age Cambodia: Temporal variations with rice agriculture. International Journal of Paleopathology 3(1):1-10. DOI: 10.1016/j.ijpp.2013.01.003. 
O’Reilly, Dougald J. W. 1999. A Diachronic Analysis of Social Organisation in the Mun River Valley. Ph.D. dissertation, University of Otago. Otago University Research Archive, Dunedin, New Zealand.

O’Reilly, Dougald J. W. 2014. Increasing complexity and the political economy model: A consideration of Iron Age moated sites in Thailand. Journal of Anthropological Archaeology 35:297-309. DOI: 10.1016/j.jaa.2014.06.007.

O’Reilly, Dougald J. W., Kate M. Domett, and Sytha Pheng. 2008. The excavation of a late prehistoric cemetery in northwest Cambodia. Udaya Journal 7:207-222. DOI:

O’Reilly, Dougald J. W., and Louise Shewan. 2015. A report on the 2011-2012 excavation of Lovea: An Iron Age, moated settlement in Cambodia. Archaeological Research in Asia 1-2:33-47. DOI: 10.1016/j.ara.2015.02.001.

O'Reilly, Dougald J. W., and Louise Shewan. 2016. Phum Lovea: A moated precursor to the pura of Cambodia? Sociopolitical transformation from Iron Age settlements to early state society. Journal of Southeast Asian Studies 47(3):468-483. DOI: 10 .1017/S002246341600028X.

O’Reilly, Dougald J. W., Louise Shewan, Kate M. Domett, and S. An. In press. Revisiting Prei Khmeng: The excavation of an Iron Age settlement and cemetery in Cambodia. Asian Perspectives.

O’Shea, John M. 1984. Mortuary Variability: An Archaeological Investigation. Academic Press, Orlando, FL.

Palubeckaitè, Žydrūné, Rimantas Jankauskas, and Jesper Boldsen. 2002. Enamel hypoplasia in Danish and Lithuanian late medieval/early modern samples: A possible reflection of child morbidity and mortality patterns. International Journal of Osteoarchaeology 12(3):189-201. DOI: 10.1002/oa.607.

Parker Pearson, Mike. 1982. Mortuary practices, society and ideology: An ethnoarchaeological study. In Symbolic and Structural Archaeology, edited by Ian Hodder. Cambridge University Press, Cambridge, pp. 99-114.

Parker Pearson, Mike. 1993. The powerful dead: Archaeological relationships between the living and the dead. Cambridge Archaeological Journal 3(2):203-229. DOI: 10.1017/S09597743 00000846.

Parker Pearson, Mike. 1999. The Archaeology of Death and Burial. Sutton Publishing Limited, Phoenix Mill.

Pechenkina, Ekaterina A., and Mercedes Delgado. 2006. Dimensions of health and social structure in the early intermediate period cemetery at Villa El Salvador, Peru. American Journal of Physical Anthropology 131(2):218-235. DOI: 10.1002/ajpa .20432 .

Pechenkina, Ekaterina A., Ma Xiaolin, and Fan Wenquan. 2017. Health status and burial status in early China. In Bones of Complexity: Bioarchaeological Case Studies of Social Organisation and Skeletal Biology, edited by Haagen D. Klaus, Amanda R. Harvey, and Mark N. Cohen. University Press of Florida, Gainesville, FL, pp. 173-203.

Peck, Joshua J. 2013. Status, health, and lifestyle in middle Iron Age Britain: A bioarcheological study of elites and non-elites from east Yorkshire, northern England. International Journal of Paleopathology 3(2):83-94. DOI: 10.1016/j.ijpp.2013.03.005.

Pedersen, Lucille T., Kate M. Domett, Nigel J. Chang, Siân E. Halcrow, Hallie R. Buckley, Charles F. W. Higham, Dougald J. W. O'Reilly, and Louise Shewan. 2019. A bioarchaeological study of trauma at late Iron Age to Protohistoric Non Ban Jak, northeast Thailand. Asian Perspectives 58(2):220-249. DOI: 10.1353 /asi.2019.0014.

Peebles, Christopher S. 1971. Moundville and surrounding sites: Some structural considerations of mortuary practices II. Memoirs of the Society for American Archaeology 25:68-91. DOI: 10 .1017/S0081130000002550.
Petré, Bo. 1993. Male and female finds and symbols in Germanic Iron Age graves. Current Swedish Archaeology 1:149-154.

Phenice, Terrell W. 1969. A newly developed visual method of sexing the os pubis. American Journal of Physical Anthropology 30(2):297-301. DOI: 10.1002/ajpa.1330300214.

Pickett, Kate E., and Richard G. Wilkinson. 2015. Income inequality and health: A causal review. Social Science \& Medicine 128:316-326. DOI: 10.1016/j.socscimed.2014.12.031.

Pietrusewsky, Michael, and Michele T. Douglas. 2002. Ban Chiang, A Prehistoric Village Site in Northeast Thailand I: The Human Skeletal Remains.University of Pennsylvania Press, Philadelphia.

Price, T. Douglas, and Gary M. Feinman. 1995. Foundations of prehistoric social inequality. In Foundations of Social Inequality, edited by T. Douglas Price and Gary M. Feinman. Plenum Press, New York. pp. 3-10.

Price, T. Douglas, and Gary M. Feinman. 2010. Social inequality and the evolution of human social organization. In Pathways to Power: New Perspectives on the Emergence of Social Inequality, edited by T. Douglas Price and Gary M. Feinman. Springer, New York. pp. 1-14.

Quinn, Colin P., and Jess Beck. 2016. Essential tensions: A framework for exploring inequality through mortuary archaeology and bioarchaeology. Open Archaeology 2(1):18-41. DOI: 10.1515 lopar-2016-0002.

Redfern, Rebecca C., and Sharon N. DeWitte. 2011. Status and health in Roman Dorset: The effect of status on risk of mortality in post-conquest populations. American Journal of Physical Anthropology 146(2):197-208. DOI: 10.1002/ajpa.21563.

Reidpath, Daniel D., Kit Y. Chan, Sandra M. Gifford, and Pascale Allotey. 2005. "He hath the French pox": Stigma, social value and social exclusion. Sociology of Health \& Illness 27(4):468489. DOI: 10.1111/j.1467-9566.2005.00452.x.

Reitsema, Laurie J., and Britney Kyle McIlvaine. 2014. Reconciling "stress" and "health" in physical anthropology: What can bioarchaeologists learn from the other subdisciplines? American Journal of Physical Anthropology 155(2):181-185. DOI: 10 .1002/ajpa.22596.

Reitsema, Laurie J., and Giuseppe Vercellotti. 2012. Stable isotope evidence for sex- and status-based variations in diet and life history at medieval Trino Vercellese, Italy. American Journal of Physical Anthropology 148(4):589-600. DOI: 10.1002/ajpa .22085 .

Renfrew, Colin, and P. Bahn. 2004. Archaeology: Theories, Methods and Practices. 4th ed. Thames and Hudson Ltd., London.

Robb, John, Renzo Bigazzi, Luca Lazzarini, Caterina Scarsini, and Fiorenza Sonego. 2001. Social "status" and biological "status": A comparison of grave goods and skeletal indicators from Pontecagnano. American Journal of Physical Anthropology 115(3): 213-222. DOI: 10.1002/ajpa.1076.

Ross, Kenneth W. 2007. Sub-Adult Identity: Attitudes towards Childhood Viewed from Mortuary Settings in Neolithic and Bronze Age Thailand. BA (Honors) dissertation, Australian National University. ANU Open Research, Canberra, Australia.

Ross, Kenneth W. 2019. The Identity at Death of the Old and Young from the Neolithic, Bronze and Iron Ages on the Southeast Asian Mainland. Ph.D. dissertation, Australian National University. ANU Open Research, Canberra, Australia.

Sapolsky, Robert M., Lewis C. Krey, and Bruce S. McEwen. 1986. The neuroendocrinology of stress and aging: The glucocorticoid cascade hypothesis. Endocrine Reviews 7(3):284-301. DOI: 10.1210/edrv-7-3-284.

Saxe, Arthur A. 1971. Social dimensions of mortuary practices in a Mesolithic population from Wadi Halfa, Sudan. Memoirs of the Society for American Archaeology 25:39-57. DOI: 10.2307 /25146711. 
Schalburg-Clayton, Jessica, Charlotte L. King, Hallie R. Buckley, Siân E. Halcrow, Charles F. W. Higham, Louise Shewan, Christina Stantis, and Kate M. Domett. 2018. Determining diet and mobility of Iron Age northeast Thailand using stable isotope analysis at the site of Non Ban Jak. Paper presented at the 21st Congress of the Indo-Pacific Prehistory Association, Hue, Vietnam.

Schour, Isaac, and Maury M. Massler. 1940. Studies in tooth development: The growth pattern of human teeth part II. The Journal of the American Dental Association 27(12):1918-1931. DOI: $10.14219 /$ jada.archive.1940.0367.

Schrader, Sarah A. 2015. Elucidating inequality in Nubia: An examination of entheseal changes at Kerma (Sudan). American Journal of Physical Anthropology 156(2):192-202. DOI: 10.1002 /ajpa.22637.

Schrader, Sarah A. 2019. Activity, Diet and Social Practice: Addressing Everyday Life in Human Skeletal Remains. Springer, Cham, Switzerland.

Scott, Glen, and Dougald O'Reilly. 2015. Rainfall and circular moated sites in north-east Thailand. Antiquity 89(347):11251138. DOI: 10.15184/aqy.2015.130.

Scott, Susan, and Christopher J. Duncan. 1999. Malnutrition, pregnancy, and infant mortality: A biometric model. Journal of Interdisciplinary History 30(1):37-60. DOI: https://www.muse .jhu.edu/article/15765.

Selye, Hans. 1950. The Physiology and Pathology of Exposure to Stress: A Treatise Based on the Concepts of the General Adaptation Syndrome and the Diseases of Adaptation. Acta, Montreal.

Selye, Hans. 1973. The evolution of the stress concept: The originator of the concept traces its development from the discovery in 1936 of the alarm reaction to modern therapeutic applications of syntoxic and catatoxic hormones. American Scientist 61(6):692-699. DOI: https://www.jstor.org/stable/27844072.

Shanks, Michael, and Christopher Tilley. 1982. Ideology, symbolic power and ritual communication: A reinterpretation of Neolithic mortuary practices. In Symbolic and Structural Archaeology, edited by Ian Hodder. Cambridge University Press, Cambridge, pp. 129-154.

Shennan, Susan. 1975. The social organization at Branč. Antiquity 49(196):279-288. DOI: 10.1017/S0003598X00070319.

Shkrum, Stephanie A. 2014. Oral Health and the Intensification of Agriculture at Ban Non Wat, Thailand. Ph.D. dissertation, University of Otago. Otago University Research Archive, Dunedin, New Zealand.

Siegrist, Johannes, and Michael Marmot. 2006. Introduction. In Social Inequalities in Health: New Evidence and Policy Implications, edited by Johannes Siegrist. Oxford University Press, Oxford, pp. 1-26.

Smith, B. Holly. 1984. Patterns of molar wear in hunter-gatherers and agriculturalists. American Journal of Physical Anthropology 63:39-56. DOI: 10.1002/ajpa.1330630107.

Stark, Miriam T. 2004. Pre-Angkorian and Ankorian Cambodia. In Southeast Asia: From Prehistory to History, edited by Ian Glover and Peter Bellwood. Routledge Curzon, London, pp. 89-119.

StataCorp. 2019. rnbreg.pdf. https://www.stata.com/manuals13 /rnbreg.pdf. Accessed 21 March.

Steckel, Richard H. 2005. Young adult mortality following severe physiological stress in childhood: Skeletal evidence. Economics \& Human Biology 3(2):314-328. DOI: 10.1016/j.ehb.2005.05 .006 .

Steptoe, Andrew, Sabine Kunz-Ebrecht, Natalie Owen, Pamela J. Feldman, Gonneke Willemsen, Clemens Kirschbaum, and Michael Marmot. 2003. Socioeconomic status and stress-related biological responses over the working day. Psychosomatic Medicine 65(3):461-470. DOI: 10.1097/01.psy.0000035717.78650.a1.
Steptoe, Andrew, and Michael Marmot. 2002. The role of psychobiological pathways in socio-economic inequalities in cardiovascular disease risk. European Heart Journal 23(1):13-25. DOI: 10.1053/euhj.2001.2611.

Stewart, Antony. 2016. Basic Statistics and Epidemiology: A Practical Guide. 4th ed. CRC Press, Boca Raton, FL.

Stewart, Marissa C., and Giuseppe Vercellotti. 2017. Application of geographic information systems to investigating associations between social status and burial location in medieval Trino Vercellese (Piedmont, Italy). American Journal of Physical Anthropology 164(1):11-29. DOI: 10.1002/ajpa.23251.

Stini, William A. 1969. Nutritional stress and growth: Sex difference in adaptive response. American Journal of Physical Anthropology 31(3):417-426. DOI: 10.1002/ajpa.1330310316.

Stinson, Sara. 1985. Sex differences in environmental sensitivity during growth and development. American Journal of Physical Anthropology 28(S6):123-147. DOI: 10.1002/ajpa.1330280507.

Stinson, Sara. 2012. Growth variation: Biological and cultural factors. In Human Biology: An Evolutionary and Biocultural Perspective, edited by Sara Stinson, Barry Bogin, and Dennis O'Rourke. 2nd ed. Wiley-Blackwell, Hoboken, NJ, pp. 587-636.

Tainter, Joseph A. 1978. Mortuary practices and the study of prehistoric social systems. Advances in Archaeological Method and Theory 1:105-141. DOI: 10.2307/20170131.

Talbot, Sarah L. 2002. From the Iron Age to Angkor in Northeast Thailand. Ph.D. dissertation, University of Otago. Otago University Research Archive, Dunedin, New Zealand.

Talbot, Sarah L. 2007. The analysis of the mortuary record. In The Origins of the Civilization of Angkor Volume II: The Excavation of Noen U-Loke and Non Muang Kao, edited by Charles F. W. Higham, Amphan Kijngam, and Sarah L. Talbot. The Fine Arts Department of Thailand, Bangkok, pp. 305-352.

Talbot, Sarah L., and Chutima Janthed. 2001. Northeast Thailand before Angkor: Evidence from an archaeological excavation at the Prasat Hin Phimai. Asian Perspectives 40(2):174-194. DOI: http://hdl.handle.net/10125/17152.

Tayles, Nancy, and Hallie R. Buckley. 2004. Leprosy and tuberculosis in Iron Age Southeast Asia? American Journal of Physical Anthropology 125(3):239-256. DOI: 10.1002/ajpa.10378.

Tayles, Nancy, and Siân E. Halcrow. 2016. Age-at-death estimation in a sample of prehistoric Southeast Asian adolescents and adults. In Bioarchaeology of Southeast Asia and the Pacific, edited by Marc F. Oxenham and Hallie R. Buckley. Routledge Handbook Series, London, pp. 239-256.

Tayles, Nancy, Siân E. Halcrow, and Kate M. Domett. 2007. The people of Noen U-Loke. In The Origins of the Civilization of Angkor, Volume II: The Excavation of Noen U-Loke and Non Muang Kao, edited by Charles F. W. Higham, Amphan Kijngam and Sarah L. Talbot. Thai Fine Arts Department, Bangkok, pp. 242-304.

Temple, Daniel H., and Alan H. Goodman. 2014. Bioarcheology has a "health" problem: Conceptualizing "stress" and "health" in bioarcheological research. American Journal of Physical Anthropology 155:186-191. DOI: 10.1002/ajpa.22602.

Terwiel, Barend Jan. 1975. Monks and Magic: An Analysis of Religious Ceremonies in Central Thailand. Scandinavian Institute of Asian Studies Monograph Series. Curzon Press, London.

Tobias, Phillip V. 1975. Anthropometry among disadvantaged peoples: Studies in southern Africa. In Biosocial Interrelations in Population Adaptation, edited by Elizabeth S. Watts, Francis E. Johnston, and Gabriel W. Lasker. Mouton, The Hague, pp. 287-305.

Torres-Rouff, Christina, Kelly J. Knudson, William J. Pestle, and Emily M. Stovel. 2015. Tiwanaku influence and social inequality: A bioarchaeological, biogeochemical, and contextual analysis of the Larache cemetery, San Pedro de Atacama, Northern 
Chile. American Journal of Physical Anthropology 158(4):592606. DOI: 10.1002/ajpa.22828.

Trigger, Bruce G. 2003. Understanding Early Civilizations. Cambrige University Press, Cambridge.

Ucko, Peter J. 1969. Ethnography and archaeological interpretation of funerary remains. World Archaeology 1(2):262-280. DOI: $10.1080 / 00438243.1969 .9979444$.

Vercellotti, Giuseppe, Barbara A. Piperata, Amanda M. Agnew, Warren M. Wilson, Darna L. Dufour, Julio C. Reina, Rosa Boano, Hedy M. Justus, Clark Spencer Larsen, Sam D. Stout, and Paul W. Sciulli. 2014. Exploring the multidimensionality of stature variation in the past through comparisons of archaeological and living populations. American Journal of Physical Anthropology 155(2):229-242. DOI: 10.1002/ajpa .22552 .

Vickery, Michael. 1998. Society, Economics, and Politics in PreAngkor Cambodia: The 7th-8th Centuries. Center for East Asian Cultural Studies for UNESCO, The Toyo Bunko.

Ward, Stacey M. 2019. The Health Impacts of Increasing Social Inequality in Late Prehistoric Northeast Thailand. Ph.D. dissertation, University of Otago. Otago University Research Archive, Dunedin, New Zealand.

Wason, Paul K. 1994. The Archaeology of Rank. Cambridge University Press, Cambridge.

Waterson, Roxana. 1995. Houses and hierarchies in island Southeast Asia. In About the House: Lévi-Strauss and Beyond, edited by Janet Carsten and Stephen Hugh-Jones. Cambridge University Press, Cambridge, pp. 47-68.

White, Joyce C., and Chureekamol Onsuwan Eyre. 2010. Residential burial and the metal age of Thailand. Archeological Papers of the American Anthropological Association 20(1):59-78. DOI: 10.1111/j.1551-8248.2011.01028.x.

Wilkinson, Richard G., and Kate E. Pickett. 2009. Income inequality and social dysfunction. Annual Review of Sociology 35(1):493-511. DOI: 10.1146/annurev-soc-070308-115926.

Wohlfarth, Barbara, Charles F. W. Higham, Kweku Afrifa Yamoah, Akkaneewut Chabangborn, Sakonvan Chawchai, and Rienk H Smittenberg. 2016. Human adaptation to mid- to lateHolocene climate change in northeast Thailand. The Holocene 26(11):1875-1886. DOI: 10.1177/0959683616645947.

Wood, James W., George R. Milner, Henry C. Harpending, and Kenneth M. Weiss. 1992. The osteological paradox: Problems of inferring prehistoric health from skeletal samples. Current Anthropology 33(4):343-370. DOI: 10.1086/204084.

Yaussy, Samantha L., and Sharon N. DeWitte. 2018. Patterns of frailty in non-adults from medieval London. International Journal of Paleopathology 22:1-7. DOI: 10.1016/j.ijpp.2018.03.008.

Yaussy, Samantha L., Sharon N. DeWitte, and Rebecca C. Redfern. 2016. Frailty and famine: Patterns of mortality and physiological stress among victims of famine in medieval London. American Journal of Physical Anthropology 160(2):272-283. DOI: 10.1002/ajpa.22954. 